\title{
Development and economic assessment of different WWTP control strategies for optimal simultaneous removal of carbon, nitrogen and phosphorus
}

\author{
*Corresponding author: George Simion Ostace \\ ${ }^{1}$ Department of Chemical Engineering. Faculty of Chemistry and Chemical \\ Engineering, Babes-Bolyai University, 400028, Cluj-Napoca. Romania. \\ email: george.ostace@ubbcluj.ro \\ Juan Antonio Baeza \\ ${ }^{2}$ Departament d'Enginyeria Química. Escola d'Enginyeria. \\ Universitat Autònoma de Barcelona, 08193, Bellaterra (Barcelona). Spain. \\ email: juanantonio.baeza@uab.cat
}

Javier Guerrero

${ }^{2}$ Departament d'Enginyeria Química. Escola d'Enginyeria.

Universitat Autònoma de Barcelona, 08193, Bellaterra (Barcelona). Spain.

email: franciscojavier.guerrero@uab.cat

\author{
Albert Guisasola \\ ${ }^{2}$ Departament d'Enginyeria Química. Escola d'Enginyeria \\ Universitat Autònoma de Barcelona, 08193, Bellaterra (Barcelona). Spain. \\ email: albert.guisasola@uab.cat \\ Vasile Mircea Cristea \\ ${ }^{1}$ Department of Chemical Engineering. Faculty of Chemistry and Chemical \\ Engineering, Babes-Bolyai University, 400028, Cluj-Napoca. Romania. \\ email: mcristea@chem.ubbcluj.ro \\ Paul Şerban Agachi \\ ${ }^{1}$ Department of Chemical Engineering. Faculty of Chemistry and Chemical \\ Engineering, Babes-Bolyai University, 400028, Cluj-Napoca. Romania. \\ email: serban.agachi@mail.ubbcluj.ro \\ Javier Lafuente \\ ${ }^{2}$ Departament d'Enginyeria Química. Escola d'Enginyeria \\ Universitat Autònoma de Barcelona, 08193, Bellaterra (Barcelona). Spain. \\ email: Javier.lafuente@uab.cat
}




\begin{abstract}
This paper presents the comparison of four control strategies for the $\mathrm{A}^{2} / \mathrm{O}$ WWTP configuration for simultaneous $\mathrm{C}, \mathrm{N}$ and $\mathrm{P}$ removal. The control strategies: i) external COD-P control; ii) external recycle flow-P control; iii) nitrate control in the last anoxic reactor; iv) ammonia control in the last aerobic reactor, were combined with other common control loops to build different control structures and were simulated in Matlab/Simulink under different influent conditions. A systematic approach was conducted with all the strategies to assess their potential effectiveness, according to the following steps: theoretical design, setpoint optimization and, finally, a detailed comparison of the control results against a reference operation and an optimized reference scenario. The optimization of the reference operation presented a $7 \%$ reduction of the total operational cost. The simulation results showed that some control strategies further reduced 3-7.5\% the WWTP operational costs while the effluent quality is greatly improved.
\end{abstract}

\title{
KEYWORDS
}

$\mathrm{A}^{2} / \mathrm{O}, \mathrm{EBPR}$, Control, Optimization, WWTP, MPC

\section{INTRODUCTION}

As a result of stricter discharge requirements for nutrients in wastewater treatment, Biological Nutrient Removal (BNR) has become a well-established technology for removing nitrogen and phosphorus from wastewater. Although considered to be the most economical, efficient and technological sustainable process for wastewater treatment (Broughton et al., 2008), many wastewater treatment plants (WWTPs) that combine Enhanced Biological Phosphorus Removal (EBPR) and nitrification/denitrification for simultaneous $\mathrm{C}, \mathrm{N}$ and $\mathrm{P}$ removal, are confronted with process instability and even process failure, mainly due the lack of understanding regarding the microbiology of EBPR (Seviour et al., 2003; Oehmen et al., 2007; Gebremariam et al., 2011).

Phosphorus removal is accomplished by a specific group of heterotrophic bacteria that has the ability to store into their cell mass excessive quantities of polyphosphate (poly-P). These types of bacteria are called polyphosphate-accumulating organisms (PAOs) and they are enriched in the bacterial community of an activated sludge system to enhance phosphorus removal (Oehmen et. al., 2007). The stored phosphorus in the PAOs is removed with the waste sludge from the secondary settler, thereby resulting in a net removal of phosphorus during treatment. 
The $\mathrm{P}$ removal mechanism is rather complex compared to nitrification and denitrification. Three main biological processes are responsible for P removal. Under aerobic and anoxic conditions two biological processes occur: growth of the PAOs and storage of large quantities of phosphorus into their cells in the form of poy-P. The PAO obtain energy for both processes by consuming an internal polymer called Poly-Hydroxy-Alkanoate (PHA). The third process is the production of PHA. This process is represented by the uptake of short chain volatile fatty acids (VFA) which are polymerized and stored in the PAO cells in the form of PHA. The energy needed for the storage of PHA is generated by breaking down the poly-P which has high-energy bonds. As a result, the PHA storage is rate limiting for the P removal process. The PHA storage process is independent of electron acceptor condition but is highly dependent on the available fermentation products (e.g. acetate) (Randall et al., 1997). Under anaerobic conditions the denitrifying ordinary heterotrophic organisms (dOHO) activity is inhibited due to the lack of electron acceptors and therefore the acetate $\left(\mathrm{S}_{\mathrm{A}}\right)$ is only used by the PAOs for the PHA storage process. Consequently the anaerobic reactor is, to some extent, mandatory for a stable EBPR process (Appeldoorm et al., 1992; Henze et al., 1999; Oehmen et al., 2007).

Besides the complex mechanisms for P removal, the dynamic nonlinear behavior of the entire process, due to the complex behavior of the bacterial communities (Maria, 2004) and the large variations in feed flows and feed concentrations, makes the BNR process hard to predict and control. Finding the proper operational conditions is not a trivial task. Excessive aeration in the aerobic reactors of the plant can lead to an increased nitrate concentration in the secondary settler, which is recycled to the anaerobic part of the plant inhibiting the EBPR process (Kuba et al., 1994; Patel and Nakhla, 2006). The presence of nitrate or nitrite in the anaerobic reactor decreases the conversion of complex carbon sources to VFA by fermentative processes (Guerrero et al., 2011a) and therefore slowly leads to EBPR failure due to lack of VFA availability for PAO growth. Also there are some hypotheses that some denitrification intermediates like nitrite or nitric oxide could have an inhibitory effect over the PAO community (Saito et al., 2004). On the other hand, a low aeration leads to an insufficient nitrification process and therefore compromises the nitrogen removal capabilities of the WWTP.

The development of reliable mathematical models that describe simultaneous $\mathrm{P}, \mathrm{C}$ and $\mathrm{N}$ removal (Henze et al., 1999; Marsili-Libelli et al. 2001; Sin and Vanrolleghem, 2006) proved to be important for predicting the process behavior and developing new control strategies, which are meant to bring a proper balance between effluent pollutants and operational costs. 
Model-based optimization of WWTPs configuration has been used for design purposes (Rivas et al., 2008), while the utilization of automatic control systems has improved the performance of numerous WWTP (Benedetti et al., 2010; Cecil and Kozlowska, 2010). Most of the control strategies reported in literature regarding the WWTP operation improvement are based only on C and N removal (Baeza, et al., 2002; Shen et al., 2008; Holenda, et al., 2008; Cristea et al., 2011, Ostace et al., 2011), but some recent works are focusing on extending this improvement to P removal (Machado et al., 2009; Guerrero et al., 2011b).

Based on all above considerations, the main objective of this work was to develop innovative control strategies that are meant to increase the stability of the EBPR process and reduce operational costs. One of the key features of the control strategies was the external carbon addition in the first anaerobic reactor of the plant. The external carbon addition has the role of providing sufficient VFA into the system to enhance the production of PHA and therefore improve P removal. Several external carbon sources have been studied to balance the COD deficiency in wastewaters (Gerber et al., 1986; Jones, et al., 1987; Winter, 1989; Appeldoorm, et al., 1992; Isaacs et al., 1994; Hallin. et al., 1996; Guerrero et al., 2012; Tayà et al., 2012). Among those, acetic and propionic acids were suggested as the most effective carbon sources for improving BNR. The results obtained show the potential of the proposed control strategies to fulfill the desired effluent quality while diminishing the operational costs.

\section{MATERIALS AND METHODS}

\subsection{Simulated plant description}

One of the most common WWTP configurations for simultaneous biological C/N/P removal is the continuous anaerobic-anoxic-oxic $\left(\mathrm{A}^{2} / \mathrm{O}\right)$ system. The $\mathrm{A}^{2} / \mathrm{O}$ configuration is a Modified Ludzack-Ettinger (MLE) process that is preceded by an anaerobic stage which is crucial for the EBPR process and has the role of enriching the sludge in PAO biomass.

The WWTP layout used for this study was identical to the one proposed by Gernaey and Jørgensen (2004). The simulated plant has seven continuous stirred tank reactors (CSTRs) named R1 to R7, arranged in series and followed by as secondary settler. Because the WWTP proved to be overloaded resulting in a violation of the effluent limits of more than $60 \%$, the total volume of the reactors was increased from $6749 \mathrm{~m}^{3}$ to $15000 \mathrm{~m}^{3}$. As a result, each aerated reactor (R5, R6 and R7) had a volume of $3000 \mathrm{~m}^{3}$ and each anoxic reactor (R3 and R4) had a volume of $1500 \mathrm{~m}^{3}$ as presented in Nopens et al. (2010). The aeration was modeled 
using the volumetric mass transfer coefficient $\left(\mathrm{k}_{\mathrm{L}} \mathrm{a}\right)$. The default values for R5 and R6 were 120 1/d. The $\mathrm{k}_{\mathrm{L}} \mathrm{a}$ in the last aerated reactor (R7) was reduced from 60 1/d (Nopens et al. 2010) to $30 \mathrm{1} / \mathrm{d}$ to induce a partial decrease of the plant nitrification capacity and as a result an improvement of the biological P removal process.

Reactors R1 and R2 are operated under anaerobic conditions to favor the uptake of organic carbon by PAO and therefore enhancing EBPR occurrence. Each anaerobic reactor has a volume of $1500 \mathrm{~m}^{3}$. A schematic representation of the plant layout is presented in Figure 1.

Figure 1 Scheme of the $\mathrm{A}^{2} / \mathrm{O}$ simulated plant for simultaneous $\mathrm{C} / \mathrm{N} / \mathrm{P}$ removal.

The reactors are followed by a secondary settler that is modeled using the 10-layer model proposed by Takács et al. (1991). The secondary settler is considered non-reactive and has a volume of $6000 \mathrm{~m}^{3}$ with a horizontal cross-section of $1500 \mathrm{~m}^{2}$ and a depth of $4 \mathrm{~m}$.

The plant has two recycle flows. The external recycle flow $\left(\mathrm{Q}_{\mathrm{REXT}}\right)$ returns the biomass from the bottom of the settler to R1 where it is mixed with the influent. The default $\mathrm{Q}_{\mathrm{REXT}}$ value is $100 \%$ of the influent flow rate $\left(\mathrm{Q}_{\mathrm{INT}}\right)$ under dry weather conditions (average of 18446 $\mathrm{m}^{3} /$ day). The second recycle flow is the nitrate recycle ( $\left.Q_{\text {RINT }}\right)$ from $\mathrm{R} 7$ to $\mathrm{R} 3$ at a default flow rate of $300 \%$ of the influent flow rate (dry weather conditions: average of 55338 $\mathrm{m}^{3} /$ day).

The $\mathrm{A}^{2} / \mathrm{O}$ system has an external carbon source which is added to the $\mathrm{R} 1$, with the aim to improve phosphorus removal and denitrification. The flow of the external carbon is constrained to a maximum of $5 \mathrm{~m}^{3} / \mathrm{d}$ and the carbon source is considered to be acetate with a concentration of $400 \mathrm{~g} / \mathrm{L}$. The default external carbon flow is $0 \mathrm{~m}^{3} / \mathrm{d}$.

The kinetic model used to describe the simultaneous C/N/P removal was ASM2d (Henze et al. 1999) with the equations for biomass decay modified to make the decay process rates electron acceptor dependent as presented in Gernaey and Jørgensen (2004). In this way the simulation results are more realistic and the development of PAO is promoted.

The dynamic influents used for the simulations were those specified in the Dry-2, Rain-2 and Storm-2 files from Gernaey and Jørgensen (2004), which contains 14 days of data at an interval of 15 minutes.

The simulated model was implemented in the Matlab/Simulink platform. To reduce the simulation time and spare the computer resources, the mathematical model was written as $\mathrm{C}$ code and compiled in a Matlab executable file. The control strategies were simulated for 28 days for each influent file using as starting point the steady state solution as proposed by 
Copp et al. (2002). Steady state was reached by simulating the plant for 100 days with constant influent which was defined by the flow-weighted dry weather data file.

\subsection{Performance assessment}

The performance of the proposed control strategies was assessed from three points of view: total operational costs, quality of the effluent and pollutant removal. The total operational costs were calculated using Eq. (1) (Vanrolleghem and Gillot, 2006):

$$
O C=\gamma_{E}(A E+P E)+\gamma_{C} E C+\gamma_{S P} S P+E F
$$

where: $A E$ represents the aeration energy $\left(\mathrm{kWh} \cdot \mathrm{d}^{-1}\right) ; P E$ - the pumping energy $\left(\mathrm{kWh} \cdot \mathrm{d}^{-1}\right) ; E C$ - external carbon addition; SP - sludge production; $E F$ - effluent fines; $\gamma_{E}$ - electricity price ( $0.1 € / \mathrm{kWh} w w w . e n e r g y . e u) ; \gamma_{C}-$ carbon addition price $(0.5 € / \mathrm{kg} w w w . i c i s p r i c i n g . c o m) ; \gamma_{S P}$ - cost for the treatment of $1 \mathrm{~kg}$ of produced sludge $(0.16 € / \mathrm{kg})$.

The average aeration energy cost was calculated using equation (2) as proposed by Nopens $e t$ al. (2010).

$$
A E=\frac{S_{o}^{s a t}}{T \cdot 1.8 \cdot 1000} \int_{t=22 d}^{t=28 d} V_{i} \cdot K_{L} a_{i}(t) d t
$$

where: $K_{L} a_{i}(t)$ is the mass transfer coefficient in the $i^{\text {th }}$ aerated reactor at time $t$ [hour $\left.{ }^{-1}\right], \mathrm{T}=7$ days, $\mathrm{V}_{\mathrm{i}}$ reactor volume $\left[\mathrm{m}^{3}\right], S_{o}^{\text {sat }}$ oxygen saturation concentration $[\mathrm{mg} / \mathrm{L}]$.

The pumping energy (equation 3) requirements were calculated with equation (3) Alex et al. (2008):

$$
P E=\frac{1}{T} \int_{t=22 d}^{t=28 d}\left(0.004 \cdot Q_{R I N T}(t)+0.008 \cdot Q_{R E X T}(t)+0.05 \cdot Q_{W}(t)\right) d t
$$

The external carbon addition (equation 4) was represented by the average external mass flow where CODs is the concentration of the carbon source and $\mathrm{Q}_{\mathrm{COD}}$ is the external carbon volumetric flow $\left(\mathrm{m}^{3} \cdot \mathrm{d}^{-1}\right)$ Alex et al. (2008): 


$$
E C=\frac{C O D s}{T \times 1000} \int_{t=22 d}^{t=28 d} Q_{C O D} d t
$$

The sludge production (SP) was calculated with equation (5) (Machado et al. 2009).

$$
S P=\frac{1}{T} \int_{t=22 d}^{t=28 d}\left(T S S_{W}(t) Q_{W}(t)\right) d t
$$

where $\mathrm{TSS}_{\mathrm{W}}$ is the Total Suspended Solids (TSS) concentration in the purge and is estimated via mass balance with equation (6).

$$
T S S_{W}(t)=\left(\frac{Q_{I N T}(t)+Q_{R E X T}(t)}{Q_{W}(t)+Q_{R E X T}(t)}\right) T S S_{R 7}(t)
$$

where $\mathrm{TSS}_{\mathrm{R} 7}$ is the TSS concentration in the R7 and $\mathrm{Q}_{\mathrm{INT}}$ is the inlet flow.

The effluent fines (Carstensen, 1994; Vanrolleghem et al., 1996) were calculated by comparing the total nitrogen, total phosphorus and ammonium concentrations in the effluent to their maximal allowable discharge limits. For each type of pollutant, two hypothetical discharge costs are attributed. A lower cost when the pollutant is below the discharge limit and a higher cost when this limit is exceeded. Hence, the effluent pollutant concentrations are transformed into monetary units by multiplying the quantity of each pollutant with their discharge costs. A mathematical description of the cost function used for the effluent fines is presented in equation (7).

$$
E F(t)=\left\{\begin{array}{lll}
\Delta \alpha_{j} \cdot C_{e f . j} \cdot Q_{e f} & \text { if } \quad C_{e f . j} \leq C_{L j} \\
\Delta \alpha_{j} \cdot C_{L j} \cdot Q_{e f}+\beta_{0 j} \cdot Q_{e f}+ & \\
+\Delta \beta_{j} \cdot\left(C_{e f . j}-C_{L j}\right) \cdot Q_{e f} & \text { if } \quad C_{e f . j}>C_{L j}
\end{array}\right.
$$

The total nitrogen and ammonia parameter values used in this research were obtained from Stare et al. (2007). The total phosphorus parameters were assumed to be three times higher than the ammonium parameters. The effluent discharge limits for ammonia, total nitrogen and total phosphorus were obtained from the Council Directive 91/271/EEC. The total nitrogen and phosphorus were calculated as presented by Gernaey and Jørgensen (2004). The parameters and effluent discharge limits used to compute the $E F$ are listed in Table 1.

Table 1 Parameters used for the effluent fines calculation. 
The effluent violations were calculated for six terms: ammonium, total phosphorus, total nitrogen, $\mathrm{BOD}_{5}$, total COD and TSS. The effluent violations were defined by the periods of time that pollutants are above their discharge limits (Time above limits, TAL). The effluent discharge limit for $\mathrm{BOD}_{5}, \mathrm{COD}$ and TSS are $10 \mathrm{mg} / \mathrm{L}, 100 \mathrm{mg} / \mathrm{L}$ and $30 \mathrm{mg} / \mathrm{L}$, respectively.

\subsection{Control methods}

Decentralized control is an appreciated and widely used control approach in industry, although full multivariable controllers may show conceptual incentives. The popularity of decentralized control relies on the following reasons: its implementation is straightforward and better understood by the operators and the redesign of the decentralized control in cases of measurement instrumentation failures or startup-shutdown procedures is less demanding compared to multivariable control (Hovd et al., 1994). The design of the decentralized control structures implies two steps. The first step sets up the structure of the control system by pairing the controlled and manipulated variables and the second one performs the design and tuning of each control loop.

A good pairing of control variables implies the use of a manipulated variable that presents the major influence over a controlled variable, avoiding interactions with other output variables. The classical tool for deciding this pairing is the relative gain array (RGA) (Bristol, 1966). The RGA was applied by Machado et al. (2009) to a similar WWTP using square configurations but, when the number of inputs and outputs is not the same, a non-square relative gain array (NSRGA) approach is recommended The NSRGA was proposed by Chang and $\mathrm{Yu}$ (1990) and it is an extension of the RGA to non-square systems. The NSRGA matrix is calculated using the formula:

$$
N \operatorname{SRGA}(s)=G(s) \times\left(G(s)^{\dagger}\right)^{T}
$$

where the.$\times$ symbol represents the Hadamard or Shur product which denotes element-byelement multiplication, $G(s)$ is the process transfer matrix and $G(s)^{\dagger}$ represents the MoorePenrose pseudo-inverse process transfer matrix.

The setpoints of the control strategies were optimized using a pattern search (PS) algorithm so that the total operational costs of the WWTP were minimized as much as possible (equation 
1). The PS algorithm operates by finding a sequence of points, called pattern, that approach an optimal point. The value of the objective function either decreases or remains the same from each point in the sequence to the next. The pattern expands or shrinks depending on whether any point within the pattern has a lower objective function value than the current point and the search is stopped after a minimum pattern size has been reached. As a result, this behavior of the PS algorithm has the potential to avoid a local minimum that is not the global minimum (Doherty et al., 2004). For the performance assessment and setpoints optimization only the last seven days of the simulation were taken into consideration. The initial condition for each optimization was the mean value of the open loop operation of the WWTP.

\section{RESULTS AND DISCUSSION}

\subsection{Development of control approaches}

Table 2 presents the $3 \times 6$ transfer function model of the WWTP. The plant model was obtained by system identification tests under normal operational conditions and each transfer function represents the relationship between a potentially control input and a control output. These transfer functions represented accurately the behavior of the WWTP in the operational range studied in this work, because the identification procedure applied to other operational points inside this range presented similar results.

Table $23 \times 6$ Transfer function model of the simulated WWTP.

The system identification was performed using the so called step tests to generate data that holds information about the process dynamics close to the normal operating conditions. For all identification tests the dissolved oxygen control loops in R5, R6 and R7 were closed using PI controllers. The DO setpoint values used for the test were $1.5 \mathrm{mg} / \mathrm{L}$ for reactor 5 and 6 , and 0.75 for R7. Also, sludge retention time (SRT) was maintained around 10 days by controlling the TSS concentration in R7 at a value of $3850 \mathrm{mg} / \mathrm{L}$ using a PI controller. The manipulated variable for the $\mathrm{TSS}_{\mathrm{R} 7}$ control was $\mathrm{Q}_{\mathrm{W}}$, which was constrained between 300 and $450 \mathrm{~m}^{3} / \mathrm{d}$. The data was collected at an interval of $15 \mathrm{~min}$.

The system variables chosen as inputs were $\mathrm{Q}_{\mathrm{COD}}, \mathrm{Q}_{\mathrm{RINT}}$ and $\mathrm{Q}_{\mathrm{REXT}}$. The output variables chosen for this study were: soluble phosphorus $\left(\mathrm{S}_{\mathrm{PO} 4}\right)$ in reactor $2(\mathrm{R} 2), \mathrm{S}_{\mathrm{PO} 4}$ in $\mathrm{R} 4, \mathrm{~S}_{\mathrm{PO} 4}$ in $\mathrm{R} 7, \mathrm{~S}_{\mathrm{NO} 3}$ in $\mathrm{R} 4$, nitrate and nitrite $\left(\mathrm{S}_{\mathrm{NO} 3}\right)$ in $\mathrm{R} 7$ and ammonia nitrogen $\left(\mathrm{S}_{\mathrm{NH} 4}\right)$ in $\mathrm{R} 7$. 
The NSRGA matrix used for the proper selection of decentralized control loops was calculated, for the $3 \times 6$ system, at four frequencies: $\omega=0 \mathrm{rad} \cdot \mathrm{d}^{-1}$ (static conditions), $1 \mathrm{rad} \cdot \mathrm{d}^{-1}$ (weekly conditions), $2 \pi \mathrm{rad} \cdot \mathrm{d}^{-1}$ (daily dynamic conditions) and $48 \pi \mathrm{rad} \cdot \mathrm{d}^{-1}$ (hourly dynamic conditions). The first 3 frequencies are the same reported by Machado et al. (2009) for a similar WWTP, but an additional faster frequency of $48 \pi \mathrm{rad} \cdot \mathrm{d}^{-1}$ was also studied. These frequencies were selected because they cover the whole range of variability versus time found in full-scale WWTP. Static conditions appear for long-term operation of a WWTP; weekly changes are expected following the typical pattern of working and non-working days of the week; daily changes are due to usual wastewater flow-rate profiles in a $24-\mathrm{h}$ period and finally the higher frequency is expected for fast reactions of the control loop following changes in nitrogen and phosphorus concentrations in the influent.

Table 3 - 3×6 NSRGA matrix for possible closed loop combinations at frequency $\omega=0$ $\mathrm{rad} \cdot \mathrm{d}^{-1}$ (static conditions) $2 \pi \mathrm{rad} \cdot \mathrm{d}^{-1}$ (daily dynamic conditions) and $48 \pi \mathrm{rad} \cdot \mathrm{d}^{-1}$ (hourly dynamic conditions).

Table 3 presents the NSRGA study for the frequencies $\omega=0,2 \pi$ and $48 \pi \mathrm{rad} \cdot \mathrm{d}^{-1}\left(\omega=1 \mathrm{rad} \cdot \mathrm{d}^{-1}\right.$ provided similar results to $\omega=0 \mathrm{rad} \cdot \mathrm{d}^{-1}$ ). The $3 \times 6$ NSRGA analysis shows that by increasing the frequency the pairing of the possible control loops shifts. At a frequency of $0 \mathrm{rad} / \mathrm{d}$ the recommended pairing is $\mathrm{Q}_{\mathrm{COD}}-\mathrm{S}_{\mathrm{NO} 3} \mathrm{R} 7, \mathrm{Q}_{\mathrm{RINT}}-\mathrm{S}_{\mathrm{NO} 3} \mathrm{R} 4$ and $\mathrm{Q}_{\mathrm{REXT}}-\mathrm{S}_{\mathrm{PO} 4} \mathrm{R} 2$ while at daily and hourly dynamic conditions the recommended pairing is $Q_{\mathrm{REXT}}-\mathrm{S}_{\mathrm{NO} 3} \mathrm{R} 7, \mathrm{Q}_{\mathrm{RINT}}-\mathrm{S}_{\mathrm{NO}}$ $\mathrm{R} 4$ and $\mathrm{Q}_{\mathrm{COD}}-\mathrm{S}_{\mathrm{PO} 4} \mathrm{R} 2$. This shift is an evidence of instability of the closed loop system under dynamic conditions. As a result the NSRGA analysis was repeated for $2 \times 6$ systems $\left(\mathrm{Q}_{\mathrm{COD}} / \mathrm{Q}_{\mathrm{RINT}}\right.$ and $\left.\mathrm{Q}_{\mathrm{RINT}} / \mathrm{Q}_{\mathrm{REXT}}\right)$ for the same frequencies.

Table $42 \times 6$ NSRGA matrix for possible closed loop combinations for $\mathrm{Q}_{\mathrm{COD}} / \mathrm{Q}_{\mathrm{RINT}}$ at frequency $\omega=0 \mathrm{rad} \cdot \mathrm{d}^{-1}$ (static conditions) $2 \pi \mathrm{rad} \cdot \mathrm{d}^{-1}$ (daily dynamic conditions) and $48 \pi$ $\mathrm{rad} \cdot \mathrm{d}^{-1}$ (hourly dynamic conditions).

Table 4 presents the NSRGA analysis for the $2 \times 6$ system with $\mathrm{Q}_{\mathrm{COD}}$ and $\mathrm{Q}_{\mathrm{RINT}}$ as possible manipulated variables. It can be observed that $\mathrm{S}_{\mathrm{PO} 4} \mathrm{R} 2$ and $\mathrm{S}_{\mathrm{NO} 3} \mathrm{R} 4$ can be independently controlled by $\mathrm{Q}_{\mathrm{COD}}$ and $\mathrm{Q}_{\mathrm{RINT}}$, respectively. It is important to emphasize that very low interdependencies are observed for all tested frequencies. Also, considering the mechanisms that explain EBPR in wastewater, pairing the external acetate addition with the phosphorus 
concentration in the second reactor is a good chose. During times with low $\mathrm{P}$ levels in the anaerobic reactors, the addition of carbon will favor the breakdown of polyphosphates by PAOs and as a result phosphate concentrations will increase due to release of orthophosphate in the system. Thus, a first control strategy can be defined. Considering the three DO control loops and the $\mathrm{TSS}_{\mathrm{R} 7}$ control loop, control strategy \#1 (CS1) has six control loops in total. The last two control loops are represented by the $\mathrm{Q}_{\mathrm{COD}}-\mathrm{S}_{\mathrm{PO} 4} \mathrm{R} 2$ and $\mathrm{Q}_{\mathrm{RINT}}-\mathrm{S}_{\mathrm{NO} 3} \mathrm{R} 4$.

Table $52 \times 6$ NSRGA matrix for possible closed loop combinations for $\mathrm{Q}_{\mathrm{RINT}} / \mathrm{Q}_{\mathrm{REXT}}$ at frequency $\omega=0 \mathrm{rad} \cdot \mathrm{d}^{-1}$ (static conditions) $2 \pi \mathrm{rad} \cdot \mathrm{d}^{-1}$ (daily dynamic conditions) and $48 \pi$ $\mathrm{rad} \cdot \mathrm{d}^{-1}$ (hourly dynamic conditions).

Table 5 presents the NSRGA analysis for the $2 \times 6$ system with $\mathrm{Q}_{\mathrm{RINT}}$ and $\mathrm{Q}_{\mathrm{REXT}}$ as possible manipulated variables. As for the previous case, two recommended pairings emerge: $Q_{\text {RINT }}$ $\mathrm{S}_{\mathrm{NO} 3} \mathrm{R} 4$ and $\mathrm{Q}_{\mathrm{REXT}}-\mathrm{S}_{\mathrm{PO} 4} \mathrm{R} 2$. In this case, the phosphorus at the end of the anaerobic stage is controlled using the external recycle flow. This control loop is feasible because nitrate from the bottom of the settler, is recycled into the anaerobic reactors via $\mathrm{Q}_{\mathrm{REXT}}$. Higher $\mathrm{Q}_{\mathrm{REXT}}$ values will bring larger quantities of nitrate in the anaerobic reactors that will trigger $\mathrm{OHO}$ activity, and therefore less VFA will be available for PAO which will lead to less release of orthophosphate. Lower $\mathrm{Q}_{\mathrm{REXT}}$ values will have the opposite effect. Therefore control strategy \#2 (CS2) was defined with six control loops, the first five loops identical to CS1 and the last control loop represented by the $\mathrm{Q}_{\mathrm{REXT}}-\mathrm{S}_{\mathrm{PO} 4} \mathrm{R} 2$. The $\mathrm{Q}_{\mathrm{REXT}}$ value was restricted to a minimum of $9223 \mathrm{~m}^{3} / \mathrm{d}$ and a maximum of $27669 \mathrm{~m}^{3} / \mathrm{d}$.

The controllers for CS1 and CS2 were designed using the Internal Model Control (IMC) approach because it provides a reasonable tradeoff between performance and robustness (Rivera et al., 1986). For the $\mathrm{Q}_{\mathrm{RINT}}-\mathrm{S}_{\mathrm{NO} 3} \mathrm{R} 4$ and $\mathrm{Q}_{\mathrm{REXT}}-\mathrm{S}_{\mathrm{PO} 4} \mathrm{R} 2$ control loops continuous PI controllers were used while for the phosphorus control loops, $\mathrm{Q}_{\mathrm{COD}}-\mathrm{S}_{\mathrm{PO} 4} \mathrm{R} 2$ and, a discrete PID controller proved to achieve a better control performance. The tuning parameters of the PI/PID controllers are presented in Table 6

Table 6 Parameters of the PI/PID controllers used for the proposed control schemes.

Because the simulation results proved that CS1 has a superior performance compared to CS2 (this will be discussed in greater detail later on), control strategy \#3 (CS3) and control strategy \#4 (CS4) had as starting point CS1. CS3 uses a cascade scheme to control the nitrate 
concentration in reactor seven. On the outer level of the cascade control architecture, a feedback Model Predictive Controller (MPC) adjusted the DO setpoint with different values for each aerated reactor, based on the desired and actual value of the nitrate $\left(\mathrm{S}_{\mathrm{NO} 3}\right)$ concentration in the third aerated reactor. The DO setpoints were constrained to a maximum of $2 \mathrm{mg} / \mathrm{L}$ to prevent excessive aeration. Also, for R5 and R6 the setpoints were constrained to a minimum of $1 \mathrm{mg} / \mathrm{L}$ to prevent under aeration and for R7 the minimum setpoint was limited to $0.25 \mathrm{mg} / \mathrm{L}$. The inner control level consisted of conventional PI controllers that keep the DO concentration in the aerated reactors at the setpoints imposed by the MPC. The other control loops of CS3 are $\mathrm{Q}_{\mathrm{COD}}-\mathrm{S}_{\mathrm{PO} 4} \mathrm{R} 2, \mathrm{Q}_{\mathrm{RINT}}-\mathrm{S}_{\mathrm{NO} 3} \mathrm{R} 4$ and $\mathrm{Q}_{\mathrm{w}}-\mathrm{X}_{\mathrm{TSS}} \mathrm{R} 7$. Control strategy \#4 was similar to CS3. The difference was that the cascade control structure had to keep the ammonia $\left(\mathrm{S}_{\mathrm{NH} 4}\right)$ concentration in reactor seven at a specific setpoint. As the name implies, MPC is a control architecture that uses a model of the plant for the prediction of the process variables, over a future finite time horizon, and for the computation of the sequence of future control moves. All the MPC algorithms have three elements in common: prediction model, objective function, and the algorithms for obtaining the control law.

The central element of the MPC is the plant model which in general, consists of, two parts: the process model and the disturbance model. Several model structures can be used to predict the future behavior of a system: impulse response, step response, transfer function model, state space model, time series model for disturbance, etc. For the present work the state space model approach for designing MPC was considered. The state space model for controller design was generated by linearization of the system at steady state operating conditions of the WWTP. The order for the linear model was chosen using a trial-and-error procedure that was meant to reduce the order as much as possible while still adequately capturing the dynamics of system. The agreement between the models used for MPC and the simulated WWTP is included in the supplementary material. The discontinuous plant models and disturbance model for the two MPC used in this paper are presented below:

Plant model for the $\mathrm{S}_{\mathrm{NO}} \mathrm{R} 7$ controller:

$$
x(k+1 \mid k)=\left[\begin{array}{ccc}
0.9037 & -0.0585 & 0.0616 \\
0.0343 & 0.8949 & 0.2414 \\
-0.0679 & 0.0992 & 0.2784
\end{array}\right] x(k)+\left[\begin{array}{ccc}
0.0012 & 0.0021 & 0.0290 \\
-0.0066 & -0.0025 & -0.0038 \\
-0.0018 & 0.0010 & 0.0098
\end{array}\right] u(k)
$$




$$
y(k)=\left[\begin{array}{lll}
8.4852 & 3.1183 & -6.0044
\end{array}\right] x(k)
$$

Plant model for the $\mathrm{S}_{\mathrm{NH}} \mathrm{R} 7$ controller:

$$
x(k+1 \mid k)=\left[\begin{array}{ccc}
0.8553 & 0.0913 & -0.0602 \\
-0.0638 & 0.8354 & 0.2781 \\
0.0703 & 0.1658 & 0.1526
\end{array}\right] x(k)+\left[\begin{array}{ccc}
0.0008 & 0.0017 & 0.0205 \\
0.0045 & 0.0017 & 0.0033 \\
0.0016 & -0.0006 & -0.0047
\end{array}\right] u(k)
$$

$$
y(k)=\left[\begin{array}{lll}
-6.0420 & 2.7056 & -4.5983
\end{array}\right] x(k)
$$

The output disturbance model used for both MPC controllers is described by:

$$
x(k+1 \mid k)=[1] x(k)+\left[6.93 \cdot 10^{-4}\right] u(k) \quad y(k)=[3981.07] x(k)
$$

where: $\mathrm{x}(\mathrm{k})$ is the state variable vector of the plant with assumed dimension $n x, \mathrm{u}(\mathrm{k})$ is the vector of manipulated variables or input variables, $\mathrm{y}(\mathrm{k})$ is the process output

The states of the plant were estimated using a Kalman filter and the control action at each time step was computed by minimizing the objective function which is presented below:

$$
\min _{\Delta u(k \mid k), \ldots, \Delta u_{m}(m-1+k \mid k)}\left\{\sum_{i=o}^{p-1}\left(\sum_{j=1}^{n_{y}}\left|w_{i+1, j}^{y}\left(y_{j}(k+1 \mid k)-r_{j}(k+1 \mid k)\right)\right|^{2}+\sum_{j=1}^{n_{u}}\left|w_{i, j}^{\Delta u} \Delta u_{j}(k+1 \mid k)\right|^{2}\right)\right\}
$$

where: "( )j" is the $\mathrm{j}$ component of a vector; $(\mathrm{k}+\mathrm{i} \mid \mathrm{k})$ value predicted for time $\mathrm{k}+\mathrm{i}$ based on the information available at time $\mathrm{k}, \mathrm{r}(\mathrm{k})$ reference vector, $w_{i, j}^{\Delta u}$ and $w_{i, j}^{y}$ weighting matrices of $\mathrm{y}$ or u.

The MPC and the state observer were built using the MPC Toolbox provided in Matlab. The MPC Toolbox automatically designs the state observer using the plant model provided by the user. The MPC controllers used a sampling time of $\Delta \mathrm{t}=5$ minutes and were tuned using the tuning rules presented in Maciejowski (2002), by performing repeated simulations and taking into consideration the overall WWTP operation assessment measures. The best parameters for both controllers were found to be: prediction horizon $\mathrm{Hp}=100$ and control horizon $\mathrm{Hc}=3$. 
Table 7 Control loops and optimal setpoints of the implemented control strategies.

Table 7 summarizes the tested control structures, details the implemented control loops and presents its optimized setpoints found with the PS algorithm.

\subsection{Sensors and actuators}

To prevent unrealistic performance of the control strategies the dynamic behavior of sensors was modeled considering available commercial probes. The continuous sensors were modeled using a series of Laplace transfer functions as presented in (Rieger et al., 2003):

$$
G_{\text {sensor }}(s)=\frac{1}{(1+T s)^{n}}
$$

where: $\mathrm{G}_{\text {sensor }}=$ transfer function of the sensor, $\mathrm{T}=\mathrm{T} 90 /$ factor $=$ time constant to achieve defined T90 time for a given $n, n=$ number of transfer functions in series.

For the dissolved oxygen control loop a continuous Hach LDO ${ }^{\circledR}$ Process Dissolved Oxygen Probe was considered. The probe has a measurement interval of $0-20.0 \mathrm{mg} / \mathrm{L}$ with a measurement noise of $\pm 0.2 \mathrm{mg} / \mathrm{L}$ and a response time (T90) of $1 \mathrm{~min}$. The DO sensors were modeled using a system order of $\mathrm{n}=2$ and time constant $\mathrm{T}=0.257 \mathrm{~min}$ (Rieger et al., 2003). For the nitrate control loops a continuous in situ Hach NO3D ${ }^{\circledR}$ sc Nitrate Sensor ion-selective electrode (ISE) was considered and for the ammonia loops the NH4D ${ }^{\circledR}$ sc Ammonium Sensor. Both probes have a measurement interval of $0.2-1000.0 \mathrm{mg} / \mathrm{L}$ with a measurement noise of \pm $0.2 \mathrm{mg} / \mathrm{L}$ and a response time (T90) of $3 \mathrm{~min}$. The nitrate and ammonia sensors were modeled using a system order of $\mathrm{n}=2$ and time constant $\mathrm{T}=0.8490 \mathrm{~min}$.

For the phosphorus control loops a PHOSPHAX ${ }^{\mathrm{TM}}$ sc Phosphate Analyzer was considered. The probe has a measurement interval of $1-50 \mathrm{mg} / \mathrm{L}$ with a measurement noise of $\pm 1 \mathrm{mg} / \mathrm{L}$, a response time (T90) of $5 \mathrm{~min}$, including sample preparation, and an adjustable measurement interval of 5-120 min. For all the simulations the sensor was considered to be set at a $5 \mathrm{~min}$ measurement interval and worked together with a Hach FILTRAX Sample Filtration System. The dynamic behavior of the aeration system, $\mathrm{k}_{\mathrm{L}} \mathrm{a}$, was modeled in the same way as for the sensors. The aeration system was considered to have a response time of T90 $=4 \mathrm{~min}$ (Rieger et $a l .$, 2006) and was modeled using a second order transfer function with a time constant of $\mathrm{T}=$ $1.03 \mathrm{~min}$. The continuous sensors and actuator models were implemented in 
Matlab/SIMULINK in form of differential and difference equations as presented in Alex et al. (2008):

$\frac{d x_{1}(t)}{d t}=\frac{1}{T} u(t)-\frac{1}{T} x_{1}(t) ; \frac{d x_{2}(t)}{d t}=\frac{1}{T} x_{1}(t)-\frac{1}{T} x_{2}(t) ; y_{1}(t)=x_{2}(t)$

\subsection{Capital, operation and maintenance costs}

Unlike the open loop operation of the plant, the implementation of advanced control strategies of the WWTP implies certain additional costs: capital, operational and maintenance costs. The capital cost is one-time expenses and it includes: purchased equipment cost (sensors, controllers, filters, auxiliary equipment) and installation costs. On the other hand, operation and maintenance costs are on a day to day basis, and can be both fixed costs and variable costs. The total capital costs for each control loop were estimated using Eq. (17), the total capital cost of each control strategy was calculated by summing up the total capital cost of the loops in the control strategy.

$T C C=C C+I C+n \times O M C+O E$

where TCC is Total Capital Cost, CC - Capital Cost, IC - Installation Cost, OMC - yearly Operational and Maintenance costs, $\mathrm{n}$ - number of years that the control strategy is in use, and $\mathrm{OE}$ is overestimation.

For this work the capital costs were considered to be the costs of purchasing sensors, controllers and filtration units. The installation cost was considered to include the price of the actual installation of the equipment and also the cost with the auxiliary equipment. The installation costs were considered to be $20 \%$ of the equipment price. The operation and maintenance costs were calculated on a yearly basis and had a value $20 \%$ of the equipment price. The overestimation was set to $10 \%$ of all the costs. Table 8 presents the estimated 5 year total capital costs (5yTCC) for each type of equipment used for the control strategies for an operation period (OP) of 5 years.

Table 8 Estimated total capital costs for each type of equipment used for the control strategies for an operation period (OP) of 5 years. 
Table 9 Estimated total capital costs for each control strategy.

Table 9 presents the estimated total capital costs for each implemented control strategy. The costs are presented for a 5 year basis and a daily basis (dTCC). The cost of the $\mathrm{TSS}_{\mathrm{R} 7}$ control loop was not accounted for because this control loop was also implemented for all the scenarios studied in this work.

\subsection{Comparison of the tested control configurations}

The results of the simulated control strategies were compared among each other and with a reference operation (RO) simulation as well. RO conditions were the same as presented in section 2.1, which provided reasonable P removal. Constant $\mathrm{k}_{\mathrm{L}}$ a values throughout all 28 days of simulation were set for each aerated reactor: $\mathrm{k}_{\mathrm{L}}$ a for the reactor five and six were set to 120 $\mathrm{d}^{-1}$ and for reactor seven to $301 / \mathrm{d}$. The $\mathrm{Q}_{\text {RINT }}$ and $\mathrm{Q}_{\mathrm{REXT}}$ values were also constant and set to $55338 \mathrm{~m}^{3} / \mathrm{d}$ and $18446 \mathrm{~m}^{3} / \mathrm{d}$ respectively. The $\mathrm{TSS}_{\mathrm{R} 7}$ control loop was closed and the TSS setpoint in R7 was set to $3850 \mathrm{mg} / \mathrm{L}$. With this configuration, the RO had a total operational cost for the dry influent file of $2378 € / d$ during the last seven days of simulation.

To have a fair comparison between the RO simulation and the control strategies, the RO configuration was optimized using the same pattern search algorithm that was used to optimize the set-points of each control strategy. The optimization algorithm returned the following values for the optimized reference operation $(\mathrm{RO}+)$ : $\mathrm{k}_{\mathrm{L}}$ a for reactor five was 156.66 $1 / \mathrm{d}, \mathrm{k}_{\mathrm{L}}$ a for reactor six had a value of $104.751 / \mathrm{d}, \mathrm{k}_{\mathrm{L}} \mathrm{a}$ in the last aerated reactor $251 / \mathrm{d}, \mathrm{Q}_{\mathrm{RINT}}$ and $Q_{\text {REXT were }} 73784 \mathrm{~m}^{3} / \mathrm{d}$ and $24107 \mathrm{~m}^{3} / \mathrm{d}$ respectively, and the external carbon addition flow had a value of $0.90 \mathrm{~m}^{3} / \mathrm{d}$. This $\mathrm{RO}+$ simulation presented a reduction in the operational costs of $166 € / d(7 \%)$ with a mean value for the last seven days of simulation of $2212 € / d$ (for the simulation with the dry influent file). The RO+ results for the rain and storm weather files were improved by $9 \%$. The main improvement of the operational costs for the RO+ was due to better total phosphorus $\left(P_{\text {tot }}\right)$ removal. The $P_{\text {tot }}$ fines costs were lowered $216-254 € / d$ depending on the influent file. For the dry influent file the effluent $\mathrm{P}_{\text {tot }}$ concentration had a value of $1.25 \mathrm{mg} / \mathrm{L}, 23 \%$ lower than the non-optimized RO. Another important cutback in the operational cost was achieved with the total nitrogen fines which were reduced with 155-211 $€ / d$ depending on the influent file. The RO+ simulation with the dry weather file returned a mean value of $9.58 \mathrm{mg} / \mathrm{L}$, compared to $11.01 \mathrm{mg} / \mathrm{L}$ for the RO. Both improvements are a 
direct result of an increased biomass in the system. The PAO population increased from a mean value of $622 \mathrm{mg} / \mathrm{L}$ to $691 \mathrm{mg} / \mathrm{L}$, hence a growth of $11 \%$. The $\mathrm{X}_{\mathrm{H}}$ biomass also presented a growth of $4 \%$, from a value of $1469 \mathrm{mg} / \mathrm{L}$ to $1528 \mathrm{mg} / \mathrm{L}$. A downside of the RO+ is a slight increase in the effluent ammonia $(1.72 \mathrm{mg} / \mathrm{L})$ concentration which is a result of a $1 \%$ lower autotrophic biomass concentration.

Table 10 summarizes the simulation results of the investigated control strategies and reference scenarios for the three tested influent files (dry, rain and storm). For the dry influent file, CS1 returned a mean value for the operational costs of $2044 € / \mathrm{d}$. By adding the daily capital cost of CS1, the total cost summed up $2093 € / d$, a reduction in the operational cost of $285 € / d$ (12\%) compared to the RO simulation and $119 € / \mathrm{d}(5 \%)$ compared to the optimized RO+ simulation. CS1 showed reduced costs for both $\mathrm{P}_{\text {tot }}$ and ammonia nitrogen, when compared to RO+. The operational cost due to $\mathrm{P}_{\text {tot }}$ fines were $31 \%$ lower (134 €/day) than for the RO+ scenario. The better P removal was a result of an increased PAO concentration with mean value of the $736 \mathrm{mg} / \mathrm{L}$, which is $6.5 \%$ higher compared to RO+. The costs with ammonia nitrogen showed an improvement of $21 \%$ (38 €/day).

Table 10 Operational costs for the control strategies (S1)-(S4), reference operation (RO) and the optimized reference operation (RO+) for all influent files.

For the simulation with the rain weather influent file, CS1 returned a mean value for the last seven days of $2848 € / d$. Therefore, an improvement of $13 € /$ day compared to the optimized RO. Adding the daily capital cost for CS1, the total cost were equal to $2897 € / d$, with $36 € / d$ more than the $\mathrm{RO}+$. The elevated costs for the rain weather scenario are a result of the higher external carbon addition requirements for the phosphorus control loop, as it can be observed in Fig. 2. During the rain event, the mean influent $\mathrm{S}_{\mathrm{PO} 4}$ concentration has a value of $5.25 \mathrm{mg} / \mathrm{L}$ which is almost $38 \%$ lower than the dry weather mean value of $8.44 \mathrm{mg} / \mathrm{L}$. As a result, the $\mathrm{S}_{\mathrm{PO} 4}$ concentration in the second anaerobic reactor drops and the controller increases the carbon addition flow in order to maintain the desired $\mathrm{S}_{\mathrm{PO} 4}$ concentration. Although the operational cost are higher, it should be noted that CS1 presents a decrease of $13 \%$ (235 €/d) in the effluent fines respect $\mathrm{RO}+$ due to the better pollutant removal performance. The CS1 simulations with the storm weather influent file returned mean operational costs, including the daily capital costs, of $2704 € / d$, with $4 \%$ (112 €/d) lower than RO+. 
Figure 2 CS1 variation of phosphorus in reactor 2 (A) and $\mathrm{Q}_{\mathrm{COD}}(\mathrm{B})$ for the dry and rain influent file.

Control strategy \#2 returned a mean value of the total operational costs of $2143 € / \mathrm{d}$ for the dry influent file. This value represents an improvement of $3 \%$ (69 €/d) compared to RO+. The cost cutback is a direct result of the phosphorus control loop in the second anaerobic reactor, which has as manipulated variable $\mathrm{Q}_{\mathrm{REXT}}$ instead of $\mathrm{Q}_{\mathrm{COD}}$, and as a result the external carbon flow is zero. The downside of this approach is that the costs with the effluent fines is higher with almost $11 \%(119 € / \mathrm{d})$ compared to the RO+ and with almost $28 \%$ (262 €/d) compared to CS1. The simulations with the rain weather influent file returned a mean value of the total operational costs of $2897 € / d$, with $497 € / d$ more than the RO+ cost and $227 € / d$ more than RO scenario. The increased operational costs using CS2 under rain weather conditions are due to a poor pollutant removal performance of the WWTP. Because the influent phosphorus concentration is lower under rain weather conditions, the $\mathrm{P}$ controller reduces to a minimum $\left(9223 \mathrm{~m}^{3} / \mathrm{d}\right.$ ) the $\mathrm{Q}_{\text {REXT }}$ value (Fig. 3B), for the whole rain period, to maintain the desired $\mathrm{P}$ concentration in the second anaerobic reactor. This fact determines an increase of more than 3 times of the TSS in the settler, from mean value of $8196 \mathrm{~kg}$ for the dry weather scenario, to $26132 \mathrm{~kg}$ for the rain event. As a result, the effluent TSS concentration increases from a mean value of $13.88 \mathrm{mg} / \mathrm{L}$ to a value of $23.75 \mathrm{mg} / \mathrm{L}$ (Fig. 3C). Because $6.7 \%$ of TSS represents phosphorus, the increase in the TSS concentration leads to an increased concentration of total $\mathrm{P}$ in the effluent, actually $94 \%$ out of the mean value of $1.86 \mathrm{mg} / \mathrm{L}$ for the rain event (day 22.5 to day 24.5) is phosphorus that originates from TSS (Fig. 3D). This high $\mathrm{P}_{\text {tot }}$ concentration, coupled with the large flow of water during this period results in a total $\mathrm{P}$ discharge during the rain event of $71.41 \mathrm{~kg}$. This value is almost 3 times higher compared to the dry weather influent file for the same time period. As a result the costs with $\mathrm{P}_{\text {tot }}$ fines have a mean value for the last seven days of simulation with the rain influent file of $835 € / \mathrm{d}$.

Figure 3 Dynamics of the CS2 under dry and rain weather conditions: A) $\mathrm{S}_{\mathrm{PO} 4}$ reactor 2; B) $\mathrm{Q}_{\text {REXT }}$; C) Effluent $\mathrm{T}_{\mathrm{SS}}$; D) Effluent $\mathrm{P}_{\text {tot }}$

The low $\mathrm{Q}_{\mathrm{REXT}}$ value also has a major effect over the TSS in the reactors. Despite the fact that during the rain event the $\mathrm{TSS}_{\mathrm{R} 7}$ controller sets the $\mathrm{Q}_{\mathrm{W}}$ at its lower limit of $300 \mathrm{~m}^{3} / \mathrm{d}$ to increase the TSS in R7, due the low $\mathrm{Q}_{\mathrm{REXT}}$ the TSS concentration in R7 drops to a mean value of $2664 \mathrm{mg} / \mathrm{L}$ from a value of $3857 \mathrm{mg} / \mathrm{L}$ during the dry event. The simulations were repeated 
with the lower $Q_{W}$ limit set at $200 \mathrm{~m}^{3} / \mathrm{d}$ and $100 \mathrm{~m}^{3} / \mathrm{d}$. The results showed that the process performance deteriorates with decreasing $\mathrm{Q}_{\mathrm{W}}$ due to a higher TSS concentration in the settler while the TSS concentration in the reactors remains the same as a result of the low $\mathrm{Q}_{\mathrm{REXT}}$. Because of the low levels of TSS in the reactors, and therefore low levels of biomass, the pollutant removal capacity of the WWTP drops drastically. As it can be observed in Table 10, CS2 also presents the highest effluent costs for ammonia (718 €/d) and total nitrogen (935 $€ / d)$. Figure 4 presents the variation for the autotrophic and heterotrophic biomass for CS2 under dry and rain operating conditions. It can be observed that during the rain event there is a decrease in both types of biomass. Figure 4 also presents the behavior of CS1 under rain operating conditions and it can be observed that in this case the drop in the biomass concentration is less significant.

Figure 4 Variation of the autotrophic (A) and heterotrophic (B) biomass for CS1 and CS2.

CS2 also presented high operational costs for the storm influent file simulations. The mean operational costs were $9 \%$ higher $(251 € / d)$ than RO+ and 13\% (363€/d) compared to CS1. Because of the poor performance of control strategy 2 in all weather conditions, control strategy 3 and 4 were based on control strategy 1 which had better performance results. Control strategy 3 , under dry weather conditions, presented a mean value for the total operational costs of $2115 € / d$. This value is $97 € / d(4 \%)$ lower than the RO+ and $263 € / d$ (11\%) compared to RO simulation. The performance of CS3 is similar to CS1, the difference in the operational costs (OC+dTCC) for the dry weather file is only $1 \%$ (22 €/d more than CS1). It can be observed in Table 11 that for both control strategies, under dry weather conditions, the differences in the effluent ammonia, $\mathrm{P}_{\text {tot }}$ and $\mathrm{N}_{\text {tot }}$ concentrations are very small. The advantages of CS3 over CS1 can be observed under rain operating conditions. In this case, CS3 has an improvement in the operational costs of $119 € / d(4 \%)$ compared to CS1. The major improvement in operational cost is due to a better ammonia removal. The mean effluent ammonia concentration has a value of $1.61 \mathrm{mg} / \mathrm{L}$ with $26 \%$ lower that CS1 (Table 11). The better ammonia removal capacity of CS3 is due to an increased aeration. The mean $\mathrm{k}_{\mathrm{L}} \mathrm{a}$ value for CS3 was 95.14 1/d, 6.6\% more compared to CS1.

For the storm influent file, control strategy 3 also presented a good performance, with an improvement in the operational costs of $114 € / d$ compared to RO+. Compared to CS1, CS3 presented an improvement of only $2 € / d$. 
Table 11 Mean effluent concentration and time above limits (TAL).

The best results were returned by control strategy 4, which showed an improvement in operational costs for the dry influent file of $162 € / \mathrm{d}(7 \%)$ compared to RO+ and $328 € / \mathrm{d}$ (14\%) compared to the non-optimized RO. CS4 presents the best pollutant removal performance with a mean value for the effluent fines of $891 € / d$. This control approach showed the best ammonia removal capacity, with a value for the ammonia EF of $77 € /$ day, this being $45 \%$ lower than CS3 which is second best considering ammonia removal. In Table 11 it can be observed that CS4 has a mean effluent ammonia value of $1.10 \mathrm{mg} / \mathrm{L}$ and time above limit of $0.59 \%$. Also, despite the better ammonia removal capacity which should have a negative effect on the $\mathrm{P}$ removal due to an increased production of nitrate, the effluent total phosphorus concentration has a value of $1.09 \mathrm{mg} / \mathrm{L}$. This performance in $\mathrm{P}$ removal is achieved due to the $\mathrm{Q}_{\mathrm{COD}}-\mathrm{S}_{\mathrm{PO} 4} \mathrm{R} 2$ control loop which provides additional carbon into the system. CS4 was the biggest external carbon consumer of all the tested control strategies. The mean value of the external COD flow was $0.90 \mathrm{~m}^{3} / \mathrm{d}, 7 \%$ more than CS3 and $5 \%$ more than CS1. Compared to RO+, CS4 used the same amount of external carbon but it used lower aeration. As a result, the PAO biomass had an increase of $6 \%$ from $691 \mathrm{mg} / \mathrm{L}$ to $730 \mathrm{mg} / \mathrm{L}$. Also, the heterotrophic biomass concentration dropped from a mean value of $1528 \mathrm{mg} / \mathrm{L}$ for the $\mathrm{RO}+$ to a value of $1438 \mathrm{mg} / \mathrm{L}$ for CS4, while the autotrophic biomass had only a drop of $2 \%$.

CS4 has the best performance for rain and storm scenario as well. The operational costs are $126 € / d$ lower for rain and $283 € / d$ for storm compared to the RO+. Considering the overall results, CS4 was demonstrated as the control strategy most able to maintain optimum operational costs linked to a proper performance and able to react successfully under influent disturbances.

Figure 5 Control strategy CS4 results for the Dry influent file: (A) Phosphate R2; (B) Nitrate nitrogen R4; (C) Ammonia R7

In Figure 5 it can be observed that CS4 presented a good control performance for all control loops despite the delay and noise of the controllers. Also, Figure 6 presented the dynamics of the manipulated variable for each control loop. It can be observed that the controllers achieve good performance and there are no extremely rapid changes in the manipulated variables and 
therefore the exploitation, of the pumping, aeration and external carbon dosage units will be efficient.

Figure 6 Control strategy CS4 dynamics of the manipulated variables: (A) External carbon addition flow; (B) $\mathrm{Q}_{\mathrm{RINT}}$; (C) $\mathrm{k}_{\mathrm{L}}$ a R5; (D) $\mathrm{k}_{\mathrm{L}}$ a R6; (E) $\mathrm{k}_{\mathrm{L}}$ a R7

The characteristics of the COD, BOD and TSS removal were not significantly changed by the control strategies when compared with the reference simulations, but the reduction of the operational costs may stand as an important incentive for their implementation.

Table 12 presents the pollutant removal performance. It can be observed that all control approaches of the WWTP achieve a total phosphorus removal of more than $86 \%$. The best $\mathrm{P}$ removal performance is achieved by CS3 and CS4 with more than 90\%, for the dry weather influent file. This means that the performance of the plant is in accordance with the 91/271/EEC Directive, although the mean effluent $P_{\text {tot }}$ concentration is above the imposed limit of $1 \mathrm{mg} / \mathrm{L}$ (Table 11). In a similar way, the total nitrogen removal is also in accordance with the 91/271/EEC Directive, the total nitrogen removal performance being between 70 $80 \%$ of the influent load.

Table 12 WWTP performance for pollutant removal.

\section{CONCLUSIONS}

This work proposed four new control approaches for a WWTP aiming at simultaneous $\mathrm{C}, \mathrm{N}$ and $\mathrm{P}$ removal. All the control strategies include control loops that aim at $\mathrm{P}$ removal improvement in addition to the more common loops designed for carbon and nitrogen removal. All the set-points of these control strategies were optimized to ensure an optimal performance. Hence, the reported results show the highest feasible performance of these control structures with fixed optimized set-points.

The simulation results with each control structure using all weather influent files were compared with the performance of a reference operation (open loop except for TSS control) and with an optimized reference operation. These results proved that:

i) The operational costs and effluent quality of the WWTP can be greatly improved using model based optimization of the reference operation. The optimized reference operation managed to improve the effluent quality and the operational costs by $7 \%$ (about 61,000 $€ /$ year) for the dry weather, and by $9 \%$ for rain and storm weather conditions. 
ii) Automatic control of the WWTP can greatly improve the operational costs of the plant while maintaining low pollutant effluent concentrations and achieving a more stable performance even under intense operation.

iii) Using the external carbon addition in the first anaerobic reactor as manipulated variable in a phosphorus control loop proved to be more efficient than using it as fix input to the plant. The $\mathrm{Q}_{\mathrm{COD}}-\mathrm{S}_{\mathrm{PO} 4} \mathrm{R} 2$ control loop proved to insure a stable EBPR process and to help produce a better effluent quality.

iv) Using the external recycle flow as manipulated variable to control $\mathrm{S}_{\mathrm{PO} 4}$ at the end the anaerobic zone proved to be a good approach only under dry weather conditions. The $\mathrm{Q}_{\mathrm{REXT}}-$ $\mathrm{S}_{\mathrm{PO} 4} \mathrm{R} 2$ control loop did not assure a stable performance under rain and storm conditions.

v) CS4 was the most efficient in all working conditions, leading to an operational cost reduction of $120,000 € /$ year for dry weather conditions. CS3 proved to be the second best due to its good performance during rain and storm events.

\section{ACKNOWLEDGEMENTS}

The authors wish to thank the financial support provided from the Romanian National Authority for Scientific Research, CNCS - UEFISCDI, project number PN-II-ID-PCE-20124-0222: Reducing Greenhouse Gas Emissions from Urban Wastewater Treatment Systems by Means of Model Based Control and Optimization.. Javier Guerrero is grateful for the grant received from the Spanish government. The authors from UAB are supported with the project CTM2010-20384 of the Spanish Ministerio de Ciencia e Innovación and are members of the GENOCOV research group (Grup de Recerca Consolidat de la Generalitat de Catalunya, 2009 SGR 815).

\section{REFERENCES}

Alex J.L., Benedetti L., Copp J., Gernaey K.V., Jeppsson U., Nopens I., Pons M.N., Rosen C., Steyer J.P., Vanrolleghem P., and Winkler S. Benchmark Simulation Model no.1 (BSM1), Tech. Report no. LUTEDX/(TEIE- 7229)/1-62/(2008).

Appeldoorm KJ, Kortstee JJ,Zehnder AJB. Biological phosphate removal by activated sludge under defined conditions. Water Res 1992; 26:453-60.

Baeza, JA, Gabriel D, and Lafuente J. Improving the nitrogen removal efficiency of an A2/O based WWTP by using on-line knowledge based expert system. Water Res 2002; 36:2109-23. 
Benedetti L, De Baets B, Nopens I, and Vanrolleghem PA. Multi-criteria analysis of wastewater treatment plant design and control scenarios under uncertainty. Environ Model Softw 2010; 25:616-21.

Bristol E.H., On a New Measure of Interaction for Multivariate Process Control, IEEE Trans. Autom. Control 1966:11, 133-4.

Broughton, B., Pratt, S., and Shilton, A.. Enhanced biological phosphorus removal for highstrength wastewater with a low rbCOD: P ratio. Bioresource Technology 2008; 99:1236-41. Carstensen J. Identification of wastewater processes. Ph.D. Thesis, Institute of Mathematical Modeling, Technical University of Denmark, 1994.

Cecil D, and Kozlowska M. Software sensors are a real alternative to true sensors. Environ Model Softw 2010; 25:622-25.

Chang, J. W., and Yu, C. C.. The relative gain for nonsquare multivariable systems. Chemical Engineering Science 1990; 45:1309-23

Copp JB. The COST Simulation Benchmark: Description and Simulator Manual.

Luxembourg: Office for Official Publications of the European Communities, 2002.

Cristea S, de Prada C, Sarabia D, and Gutierrez G. Aeration control of a wastewater treatment plant using hybrid NMPC. Comput. Chem. Eng 2011; 35:638-50.

Doherty, D., Freeman, M.A., and Kumar, R. Optimization with Matlab and the Genetic Algorithm and Direct Search Toolbox. MATLAB Digest September, 2004.

Gebremariam SY, Beutel MW, Christian D, Hess TF. Research advances and challenges in the microbiology of enhanced biological phosphorus removal--a critical review. Water Environ Res. 201;83(3):195-219.

Gerber A, Mostert ES, Winter CT, and Villiers RH. The effect of acetate and other shortchain carbon compounds on the kinetics of biological nutrient removal. Water SA. 1986; 12:7-12.

Gernaey KV, and Jørgensen SB. Benchmarking combined biological phosphorus and nitrogen removal wastewater treatment processes. Control Eng. Pract. 2004; 12:357-73.

Guerrero J, Guisasola A, and Baeza JA. The nature of the carbon source rules the competition between PAO and denitrifiers in systems for simultaneous biological nitrogen and phosphorus removal. Water Res 2011a; 45:4793-802.

Guerrero J, Guisasola A, Vilanova R, and Baeza JA. Improving the performance of a WWTP control system by model-based setpoint optimisation. Environ Model Softw 2011b; 26:492-7. Guerrero J., Tayà C., Guisasola A. and Baeza J.A. Glycerol as a sole carbon source for enhanced biological phosphorus removal. Water Res. 2012 46: 2983-2991. 
Hallin S, Rothman M, and Pell M. Adaptation of denitrifying bacteria to acetate and methanol in activated sludge. Water Res 1996; 30:1445-50.

Henze M, Gujer W, Mino T, Matsuo T, Wentzel MC, Marais GVR, and van Loosdrecht MCM. Activated sludge model no 2d, ASM2d. Water Sci. Technol. 1999; 39:165-82.

Holenda B, Domokos E, Rédey A', Fazakas J. Dissolved oxygen control of the activated sludge wastewater treatment process using model predictive control. Comput. Chem. Eng 2008; 32:1270-8.

Hovd M., Skogestad S.. Pairing Criteria for Decentralized Control of Unstable Plants, Ind. Chemical Engineering Research 1994; 33:2134-9.

Isaacs SH, Henze M., Søeberg H, and Kummel M. External carbon source addition as a means to control an activated sludge nutrient removal process. Water Res 1994; 28:511-20. Jones PH, Tadwalkar AD, and Hsu CL. Enhanced uptake of phosphorus by activated sludge: effect of substrate addition. Water Res 1987; 21:301-8.

Kuba T, Wachtmeister A, van Loosdrecht MCM, and Heijnen JJ. Effect of nitrate on phosphorus release in biological phosphorus removal systems. Water Sci. Technol 1994; 30:263-9.

Machado VC, Gabriel D, Lafuente J and Baeza JA. Cost and effluent quality controllers design based on the relative gain array for nutrient removal WWTP. Water Res 2009, 43:5129-41.

Maciejowski JM. Predictive Control with Constraints. Harlow : Prentice-Hall, 2002.

Maria G. A review of algorithms and trends in kinetic model identification. Chem. Biochem. Eng. 2004,18:195-222.

Marsili-Libelli S, Ratini P, Spagni A, and Bortone G. Implementation, study and calibration of a modified ASM2d for the simulation of SBR processes, Water Sci Technol 2001; 43:6976.

Nopens I, Benedetti L, Jeppsson U, Pons MN, Alex J, Copp JB, Gernaey KV, Rosen C Steyer, JP and Vanrolleghem PA. Benchmark Simulation model no 2: finalization of plant layout and default control strategy. Water Sci Technol 2010; 62:1967-74.

Oehmen, A., Lemos, P.C., Carvalho, G., Yuan, Z., Keller, J., Blackall, L.L., and Reis, M.A.M.. Advances in enhanced biological phosphorus removal: from micro to macro scale. Water Res. 2007; 41:2271-2300.

Ostace GS, Cristea VM, and Agachi PŞ. Cost Reduction of the Wastewater Treatment Plant operation by MPC based on modified ASM1 with two-step nitrification/denitrification model. Comput Chem Eng 2011; 35:2469-79. 
Patel J, and Nakhla G. Interaction of denitrification and P removal in anoxic P removal systems. Desalination 2006; 20:82-99.

Randall A.A., Benefield L.D., Hill W.E., Nicol J.P., Boman G.K., and Jing S.R. The effect of volatile fatty acids on enhanced biological phosphorus removal and population structure in anaerobic/aerobic sequencing batch reactors. Water Sci. Technol. 35: 153-160.

Rieger L., Alex J., Gujer W., and Siegrist H. Modelling of Aeration Systems at Wastewater Treatment Plants. Proc Water Sci Technol. 2006; 53:439-47.

Rieger L., Alex J., Winkler S., Boehler M., Thomann M., and Siegrist H. Progress in sensor technology - progress in process control? Part I: Sensor property investigation and classification. Wat. Sci. Tech., 2003; 47:103-12.

Rivas A, Irizar I, and Ayesa E. Model-based optimisation of wastewater treatment plants design. Environ Model Softw 2008; 23:35-50.

Rivera DE, Morari M, and Skogestad S. Internal Model Control. 4. PID Controller Design. Ind. Eng. Chem. Process Des. Dev 1986; 25:252-65.

Saito, T., Brdjanovic, D., and van Loosdrecht, M.C.M.,. Effect of nitrite on phosphate uptake by phosphate accumulating organisms. Water Res. 2004; 38:3760-8.

Seviour, R.J., Mino, T., and Onuki, M.. The microbiology of biological phosphorus removal in activated sludge systems. FEMS Microbiology Review 2003; 27:99-127.

Shen W, Chen X, and Corrioub J P. Application of model predictive control to the BSM1 benchmark of wastewater treatment process, Comput Chem Eng 2008; 32:2849-56.

Sin G, and Vanrolleghem PA. Evolution of an ASM2d-like model structure due to operational changes of an SBR process., Water Sci Technol 2006; 53:237-45.

Stare A, Vrecko D, Hvala N, and Strmcnik S. Comparison of control strategies for nitrogen removal in an activated sludge process in terms of operating costs. Water Res 2007; 41:200414.

Takács I, Patry GC, and Nolasco D. A dynamic model of the clarification-thickening process. Water Res 1991; 25:1263-71.

Tayà C., Guerrero J., Vanneste G., Guisasola A., and Baeza J.A. Methanol-driven enhanced biological phosphorus removal with a syntrophic consortium. Biotechnol Bioeng. 2012, DOI 10.1002/bit.24625

Vanrolleghem PA, and Gillot S. Robustness and economic measures as control benchmark performance criteria. Water Sci Technol 2002; 45:117-26. 
Vanrolleghem PA, Jeppsson U, Carstensen J, Carlsson B, and Olsson G. Integration of wastewater treatment plant design and operation e a systematic approach using cost functions. Water Sci Technol 1996; 34:159-71.

Winter CT. The role of acetate in denitrification and biological phosphate removal in modified Bardenpho systems. Water Sci Technol 1989; 21:375-385.

www.energy.eu accessed June $23^{\text {rd }} 2012$

www.icispricing.com June $23^{\text {rd }} 2012$

\section{LIST OF TABLES}

Table 1 Parameters used for the effluent fines calculation. ..................................................... 7

Table $23 \times 6$ Transfer function model of the simulated WWTP..................................................

Table $3-3 \times 6$ NSRGA matrix for possible closed loop combinations at frequency $\omega=0 \mathrm{rad} \cdot \mathrm{d}^{-}$

${ }^{1}$ (static conditions) $2 \pi \mathrm{rad} \cdot \mathrm{d}^{-1}$ (daily dynamic conditions) and $48 \pi \mathrm{rad} \cdot \mathrm{d}^{-1}$ (hourly dynamic



Table 4 2×6 NSRGA matrix for possible closed loop combinations for $\mathrm{Q}_{\mathrm{COD}} / \mathrm{Q}_{\mathrm{RINT}}$ at frequency $\omega=0 \mathrm{rad} \cdot \mathrm{d}^{-1}$ (static conditions) $2 \pi \mathrm{rad} \cdot \mathrm{d}^{-1}$ (daily dynamic conditions) and $48 \pi$ $\mathrm{rad} \cdot \mathrm{d}^{-1}$ (hourly dynamic conditions). 10

Table $52 \times 6$ NSRGA matrix for possible closed loop combinations for $\mathrm{Q}_{\mathrm{RINT}} / \mathrm{Q}_{\mathrm{REXT}}$ at frequency $\omega=0 \mathrm{rad} \cdot \mathrm{d}^{-1}$ (static conditions) $2 \pi \mathrm{rad} \cdot \mathrm{d}^{-1}$ (daily dynamic conditions) and $48 \pi$ $\mathrm{rad} \cdot \mathrm{d}^{-1}$ (hourly dynamic conditions). 11

Table 6 Parameters of the PI/PID controllers used for the proposed control schemes. 11

Table 7 Control loops and optimal setpoints of the implemented control strategies. .14

Table 8 Estimated total capital costs for each type of equipment used for the control strategies for an operation period (OP) of 5 years.

Table 9 Estimated total capital costs for each control strategy.

Table 10 Operational costs for the control strategies (S1)-(S4), reference operation (RO) and the optimized reference operation $(\mathrm{RO}+)$ for all influent files

Table 11 Mean effluent concentration and time above limits (TAL). 20

Table 12 WWTP performance for pollutant removal.

\section{LIST OF FIGURES}

Figure 1 Scheme of the $\mathrm{A}^{2} / \mathrm{O}$ simulated plant for simultaneous $\mathrm{C} / \mathrm{N} / \mathrm{P}$ removal. .5

Figure 2 CS1 variation of phosphorus in reactor 2 (A) and $\mathrm{Q}_{\mathrm{COD}}(\mathrm{B})$ for the dry and rain influent file. 
Figure 3 Dynamics of the CS2 under dry and rain weather conditions: A) SPO4 reactor 2; B)

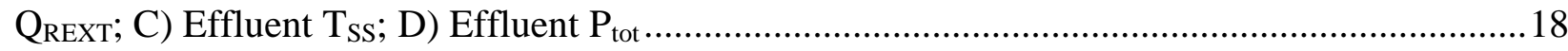

Figure 4 Variation of the autotrophic (A) and heterotrophic (B) biomass for CS1 and CS2 ........ 19

Figure 5 Control strategy CS4 results for the Dry influent file: (A) Phosphate R2; (B) Nitrate nitrogen R4; (C) Ammonia R7

Figure 6 Control strategy CS4 dynamics of the manipulated variables: (A) External carbon addition flow; (B) $\mathrm{Q}_{\mathrm{RINT}}$; (C) $\mathrm{k}_{\mathrm{L}} \mathrm{R}$ R; (D) $\mathrm{k}_{\mathrm{L}} \mathrm{a}$ R6; (E) $\mathrm{k}_{\mathrm{L}} \mathrm{a}$ R7 
Table 1 Parameters used for the effluent fines calculation.

\begin{tabular}{lllll}
\hline $\begin{array}{l}\text { Effluent } \\
\text { Variable }\end{array}$ & $\Delta \alpha_{j}(\boldsymbol{€} / \mathbf{k g})$ & $\Delta \beta_{j}(\boldsymbol{€} / \mathbf{k g})$ & $\beta_{0 j}\left(\boldsymbol{€} / \mathbf{m}^{\mathbf{3}}\right)$ & $C_{L j}(\mathbf{m g} / \mathbf{L})$ \\
\hline Ammonium & 4.00 & 12.00 & $2.70 \times 10^{-3}$ & 2.00 \\
Total Nitrogen & 2.70 & 8.10 & $1.40 \times 10^{-3}$ & 10.00 \\
Phosphorus & 12.00 & 36.00 & $2.70 \times 10^{-3}$ & 1.00 \\
\hline
\end{tabular}


Table 2. $3 \times 6$ Transfer function model of the simulated WWTP.

\begin{tabular}{|c|c|c|c|}
\hline & \multicolumn{3}{|c|}{ Inputs } \\
\hline Outputs & $\mathrm{Q}_{\mathrm{COD}}$ & $\mathrm{Q}_{\mathrm{RINT}}$ & $\mathrm{Q}_{\mathrm{REXT}}$ \\
\hline $\mathrm{S}_{\mathrm{PO} 4} \mathrm{R} 2$ & $\frac{4.935}{0.286 \mathrm{~s}+1} e^{-0.312 s}$ & $\frac{-2.187 \cdot 10^{-6}}{0.171 s+1} e^{-0.312 s}$ & $\frac{-1.289 \cdot 10^{-3}}{0.417 s+1} e^{-0.286 s}$ \\
\hline $\mathrm{S}_{\mathrm{PO} 4} \mathrm{R} 4$ & $\frac{-0.266}{1.028 s} e^{-0.312 s}$ & $\frac{-2.231 \cdot 10^{-5}}{1.091 s+1} e^{-0.202 s}$ & $\frac{1.022 \cdot 10^{-4}}{0.668 s+1} e^{-0.312 s}$ \\
\hline $\mathrm{S}_{\mathrm{PO} 4} \mathrm{R} 7$ & $\frac{-0.992}{0.748 s+1} e^{-0.036 s}$ & $\frac{-2.404 \cdot 10^{-6}}{0.864 s+1} e^{-0.312 s}$ & $\frac{1.577 \cdot 10^{-4}}{0.958 s+1} e^{-0.307 s}$ \\
\hline $\mathrm{S}_{\mathrm{NO} 3} \mathrm{R} 4$ & $\frac{-0.783}{0.486 s+1} e^{-0.069 s}$ & $\frac{-8.203 \cdot 10^{-5}}{0.588 s+1} e^{-0.307 s}$ & $\frac{-5.693 \cdot 10^{-5}}{0.161 s+1} e^{-0.312 s}$ \\
\hline $\mathrm{S}_{\mathrm{NO} 3} \mathrm{R} 7$ & $\frac{-1.010}{0.447 s+1} e^{-0.295 s}$ & $\frac{3.24 \cdot 10^{-6}}{0.539 s+1} e^{-0.295 s}$ & $\frac{-1.357 \cdot 10^{-4}}{0.206 s+1} e^{-0.307 s}$ \\
\hline $\mathrm{S}_{\mathrm{NH} 4} \mathrm{R} 7$ & $\frac{-1.010}{0.447 s+1} e^{-0.295 s}$ & $\frac{1.235 \cdot 10^{-6}}{8.210 s+1} e^{-0.239 s}$ & $\frac{-1.072 \cdot 10^{-6}}{0.840 s+1} e^{-0.291 s}$ \\
\hline
\end{tabular}


Table 3. $3 \times 6$ NSRGA matrix for possible closed loop combinations at frequency $\omega=0 \mathrm{rad} \cdot \mathrm{d}^{-1}$ (static conditions) $2 \pi \mathrm{rad} \cdot \mathrm{d}^{-1}$ (daily dynamic conditions) and $48 \pi \mathrm{rad} \cdot \mathrm{d}^{-1}$ (hourly dynamic conditions).

\begin{tabular}{|c|c|c|c|c|c|c|c|c|c|}
\hline \multirow{3}{*}{$\begin{array}{c}\text { Controlled } \\
\text { variables }\end{array}$} & \multicolumn{9}{|c|}{ Manipulated Variables } \\
\hline & \multicolumn{3}{|c|}{$\omega=0 \mathrm{rad} / \mathrm{d}$} & \multicolumn{3}{|c|}{$\omega=2 \pi \mathrm{rad} / \mathrm{d}$} & \multicolumn{3}{|c|}{$\omega=48 \pi \mathrm{rad} / \mathrm{d}$} \\
\hline & $\mathbf{Q}_{\text {COD }}$ & $\mathbf{Q}_{\text {RINT }}$ & QREXT & $\mathbf{Q}_{\text {COD }}$ & QRINT & QREXT & $\mathbf{Q}_{\text {COD }}$ & $\mathbf{Q}_{\text {RINT }}$ & QREXT \\
\hline $\mathrm{S}_{\mathrm{PO} 4} \mathrm{R} 2$ & 0.1846 & 0.0008 & & $\mathbf{0 . 5 3 5 5}$ & -0.0005 & 0.4585 & 0.6000 & -0.0004 & 0.3949 \\
\hline $\mathrm{S}_{\mathrm{PO4}} \mathrm{R} 4$ & 0.0174 & 0.0856 & -0.0197 & -0.0002 & 0.0213 & 0.0030 & 0.0002 & 0.0210 & 0.0014 \\
\hline $\mathrm{S}_{\mathrm{PO4} 4} \mathrm{R} 7$ & 0.1788 & 0.0059 & -0.0918 & 0.0341 & 0.0020 & -0.0178 & 0.0237 & 0.0017 & -0.0124 \\
\hline $\mathrm{S}_{\mathrm{NO3}} \mathrm{R} 4$ & -0.0017 & 0.9304 & -0.0004 & -0.0170 & 1.0027 & -0.0091 & -0.0165 & 1.0043 & -0.0103 \\
\hline $\mathbf{S}_{\mathrm{NO3}} \mathbf{R} 7$ & 0.6209 & -0.0231 & 0.3224 & 0.4476 & -0.0255 & 0.5655 & 0.3926 & -0.0265 & 0.6263 \\
\hline $\mathrm{S}_{\mathrm{NH} 4} \mathrm{R} 7$ & 0.0001 & 0.0003 & 0.0000 & 0.0000 & 0.0000 & 0.0000 & 0.0000 & 0.0000 & 0.0000 \\
\hline
\end{tabular}


Table 4. $2 \times 6$ NSRGA matrix for possible closed loop combinations for $\mathrm{Q}_{\mathrm{COD}} / \mathrm{Q}_{\mathrm{RINT}}$ at frequency $\omega=0 \mathrm{rad} \cdot \mathrm{d}^{-1}$ (static conditions) $2 \pi \mathrm{rad} \cdot \mathrm{d}^{-1}$ (daily dynamic conditions) and $48 \pi$ $\mathrm{rad} \cdot \mathrm{d}^{-1}$ (hourly dynamic conditions).

\begin{tabular}{|c|c|c|c|c|c|c|}
\hline \multirow{3}{*}{$\begin{array}{c}\text { Controlled } \\
\text { variables }\end{array}$} & \multicolumn{6}{|c|}{ Manipulated Variables } \\
\hline & \multicolumn{2}{|c|}{$\omega=0 \mathrm{rad} / \mathrm{d}$} & \multicolumn{2}{|c|}{$\omega=2 \pi \mathrm{rad} / \mathrm{d}$} & \multicolumn{2}{|c|}{$\omega=48 \pi \mathrm{rad} / \mathrm{d}$} \\
\hline & $\mathbf{Q}_{\text {COD }}$ & $Q_{\text {RINT }}$ & $\mathbf{Q}_{\text {COD }}$ & $\mathbf{Q}_{\text {RINT }}$ & $\mathbf{Q}_{\text {COD }}$ & $\mathbf{Q}_{\text {RINT }}$ \\
\hline $\mathrm{S}_{\mathrm{PO4}} \mathrm{R2}$ & 0.9196 & -0.0033 & 0.9795 & -0.0067 & 0.9851 & -0.0082 \\
\hline $\mathrm{S}_{\mathrm{PO4}} \mathrm{R4}$ & 0.0049 & 0.0726 & 0.0007 & 0.0230 & 0.0006 & 0.0219 \\
\hline $\mathbf{S}_{\mathbf{P O 4}} \mathbf{R 7}$ & 0.0383 & 0.0017 & 0.0077 & 0.0007 & 0.0062 & 0.0007 \\
\hline $\mathrm{S}_{\mathrm{NO3}} \mathrm{R4}$ & -0.0003 & 0.9285 & -0.0067 & 0.9822 & -0.0082 & 0.9848 \\
\hline $\mathbf{S}_{\mathrm{NO3}} \mathbf{R} 7$ & 0.0375 & 0.0003 & 0.0188 & 0.0008 & 0.0162 & 0.0008 \\
\hline $\mathbf{S}_{\mathrm{NH} 4} \mathbf{R 7}$ & 0.0000 & 0.0002 & 0.0000 & 0.0000 & 0.0000 & 0.0000 \\
\hline
\end{tabular}


Table 5. $2 \times 6$ NSRGA matrix for possible closed loop combinations for $Q_{R I N T} / Q_{\text {REXT }}$ at frequency $\omega=0 \mathrm{rad} \cdot \mathrm{d}^{-1}$ (static conditions) $2 \pi \mathrm{rad} \cdot \mathrm{d}^{-1}$ (daily dynamic conditions) and $48 \pi$ $\mathrm{rad} \cdot \mathrm{d}^{-1}$ (hourly dynamic conditions).

\begin{tabular}{|c|c|c|c|c|c|c|}
\hline \multirow{3}{*}{$\begin{array}{c}\text { Controlled } \\
\text { variables }\end{array}$} & \multicolumn{6}{|c|}{ Manipulated Variables } \\
\hline & \multicolumn{2}{|c|}{$\omega=0 \mathrm{rad} / \mathrm{d}$} & \multicolumn{2}{|c|}{$\omega=2 \pi \mathrm{rad} / \mathrm{d}$} & \multicolumn{2}{|c|}{$\omega=48 \pi \mathrm{rad} / \mathrm{d}$} \\
\hline & QRINT $_{\text {R }}$ & Q $_{\text {REXT }}$ & Q RINT & QREXT & QRINT $_{\text {R }}$ & $\mathbf{Q}_{\text {REXT }}$ \\
\hline $\mathrm{S}_{\mathrm{PO} 4} \mathrm{R2}$ & 0.0018 & 0.9699 & 0.0069 & 0.9592 & 0.0115 & 0.9448 \\
\hline $\mathbf{S}_{\mathrm{PO4}} \mathrm{R} 4$ & 0.0679 & 0.0052 & 0.0217 & 0.0023 & 0.0206 & 0.0020 \\
\hline $\mathbf{S}_{\mathrm{PO} 4} \mathbf{R} 7$ & 0.0006 & 0.0144 & 0.0004 & 0.0030 & 0.0003 & 0.0026 \\
\hline $\mathbf{S}_{\mathrm{NO3}} \mathrm{R} 4$ & 0.9282 & 0.0000 & 0.9695 & 0.0045 & 0.9661 & 0.0081 \\
\hline $\mathbf{S}_{\mathrm{NO3}} \mathbf{R 7}$ & 0.0013 & 0.0106 & 0.0015 & 0.0310 & 0.0015 & 0.0424 \\
\hline $\mathbf{S}_{\mathrm{NH} 4} \mathbf{R 7}$ & 0.0002 & 0.0000 & 0.0000 & 0.0000 & 0.0000 & 0.0000 \\
\hline
\end{tabular}


Table 6. Parameters of the PI/PID controllers used for the proposed control schemes.

\begin{tabular}{cccccc}
\hline $\begin{array}{c}\text { Manipulated } \\
\text { variable }\end{array}$ & $\begin{array}{c}\text { Controlled } \\
\text { variable }\end{array}$ & $\begin{array}{c}\text { Type of } \\
\text { controller }\end{array}$ & Kc & $\begin{array}{c}\text { Ti } \\
\text { [days] }\end{array}$ & $\begin{array}{c}\text { Td } \\
\text { [days] }\end{array}$ \\
\hline $\mathrm{Q}_{\mathrm{COD}}$ & $\mathrm{S}_{\mathrm{PO} 4} \mathrm{R} 2$ & $\mathrm{PID}$ & 0.4148 & 0.4432 & 0.1012 \\
$\mathrm{Q}_{\mathrm{REXT}}$ & $\mathrm{S}_{\mathrm{PO} 4} \mathrm{R} 2$ & $\mathrm{PI}$ & -1900.3 & 0.56 & - \\
$\mathrm{Q}_{\mathrm{RINT}}$ & $\mathrm{S}_{\mathrm{NO} 3} \mathrm{R} 4$ & $\mathrm{PI}$ & 34635 & 0.74 & - \\
$\mathrm{Q}_{w}$ & $\mathrm{X}_{\mathrm{TSS}} \mathrm{R} 7$ & $\mathrm{PI}$ & -4.9246 & 17 & - \\
$\mathrm{k}_{\mathrm{L}} \mathrm{R} 5$ & $\mathrm{~S}_{\mathrm{O} 2} \mathrm{R} 5$ & $\mathrm{PI}$ & 100 & 0.01 & - \\
$\mathrm{k}_{\mathrm{L}} \mathrm{R} 6$ & $\mathrm{~S}_{\mathrm{O} 2} \mathrm{R} 6$ & $\mathrm{PI}$ & 100 & 0.01 & - \\
$\mathrm{k}_{\mathrm{L}} \mathrm{a}$ R7 & $\mathrm{S}_{\mathrm{O} 2} \mathrm{R} 7$ & $\mathrm{PI}$ & 100 & 0.01 & - \\
\hline
\end{tabular}


Table 7. Control loops and optimal setpoints of the implemented control strategies.

\begin{tabular}{|c|c|c|c|c|c|}
\hline & $\begin{array}{l}\text { Controlled } \\
\text { parameter }\end{array}$ & $\begin{array}{l}\text { Controller } \\
\text { algorithm }\end{array}$ & $\begin{array}{l}\text { Manipulated } \\
\text { variable }\end{array}$ & $\begin{array}{c}\text { Manipulated } \\
\text { variable constrains }\end{array}$ & $\begin{array}{c}\text { Optimal } \\
\text { Setpoint } \\
(\mathrm{mg} / \mathrm{L})\end{array}$ \\
\hline \multirow{3}{*}{$\begin{array}{c}\text { Control } \\
\text { loops } \\
\text { for CS1 }\end{array}$} & $\mathrm{S}_{\mathrm{O} 2}$ in $\mathrm{R} 5, \mathrm{R} 6, \mathrm{R} 7$ & PI & $\mathrm{k}_{\mathrm{L}} \mathrm{a}$ in $\mathrm{R} 5, \mathrm{R} 6, \mathrm{R} 7$ & $0-160 \mathrm{~d}^{-1}$ & {$[1.11,1.45,0.27]$} \\
\hline & $\mathrm{S}_{\mathrm{NO} 3}$ in $\mathrm{R} 4$ & PI & $\mathrm{Q}_{\mathrm{RINT}}$ & $0-92230 \mathrm{~m}^{3} / \mathrm{d}$ & 1.98 \\
\hline & $\mathrm{S}_{\mathrm{PO} 4}$ in $\mathrm{R} 2$ & PID & COD addition & $0-5 \mathrm{~m}^{3} \cdot \mathrm{d}^{-1}$ & 27.00 \\
\hline \multirow{3}{*}{$\begin{array}{c}\text { Control } \\
\text { loops } \\
\text { for CS2 }\end{array}$} & $\mathrm{S}_{\mathrm{O} 2}$ in $\mathrm{R} 5, \mathrm{R} 6, \mathrm{R} 7$ & PI & $\mathrm{k}_{\mathrm{L}} \mathrm{a}$ in $\mathrm{R} 5, \mathrm{R} 6, \mathrm{R} 7$ & $0-160 d^{-1}$ & {$[1.00,1.00,0.25]$} \\
\hline & $\mathrm{S}_{\mathrm{NO} 3}$ in $\mathrm{R} 4$ & PI & $\mathrm{Q}_{\mathrm{RINT}}$ & $0-92230 \mathrm{~m}^{3} / \mathrm{d}$ & 2.00 \\
\hline & $\mathrm{S}_{\mathrm{PO} 4}$ in $\mathrm{R} 2$ & PI & $\mathrm{Q}_{\text {REXT }}$ & $9223-27669 \mathrm{~m}^{3} / \mathrm{d}$ & 27.00 \\
\hline \multirow{4}{*}{$\begin{array}{c}\text { Control } \\
\text { loops } \\
\text { for CS3 }\end{array}$} & \multirow{2}{*}{$\mathrm{S}_{\mathrm{NO} 3}$ in $\mathrm{R} 7$} & $\begin{array}{l}\text { Supervisory } \\
\text { MPC }\end{array}$ & $\mathrm{S}_{\mathrm{O} 2} \mathrm{SP}$ in $\mathrm{R} 5, \mathrm{R} 6, \mathrm{R} 7$ & $\begin{array}{c}1-2 \mathrm{mg} / \mathrm{L} \mathrm{R} 5 \text { and R6 } \\
0.25-2 \mathrm{mg} / \mathrm{L} \mathrm{R} 7\end{array}$ & 7.00 \\
\hline & & Slave PI & $\mathrm{k}_{\mathrm{L}} \mathrm{a}$ in $\mathrm{R} 5, \mathrm{R} 6, \mathrm{R} 7$ & $0-160 \mathrm{~d}^{-1}$ & Imposed by MPC \\
\hline & $\mathrm{S}_{\mathrm{NO} 3}$ in $\mathrm{R} 4$ & PI & $\mathrm{Q}_{\mathrm{RINT}}$ & $0-92230 \mathrm{~m}^{3} / \mathrm{d}$ & 2.00 \\
\hline & $\mathrm{S}_{\mathrm{PO} 4}$ in $\mathrm{R} 2$ & PID & COD addition & $0-5 \mathrm{~m}^{3} / \mathrm{d}$ & 27.00 \\
\hline \multirow{4}{*}{$\begin{array}{l}\text { Control } \\
\text { loops } \\
\text { for CS4 }\end{array}$} & \multirow{2}{*}{$\mathrm{S}_{\mathrm{NH} 4}$ in $\mathrm{R} 7$} & $\begin{array}{l}\text { Supervisory } \\
\text { MPC }\end{array}$ & $\mathrm{S}_{\mathrm{O} 2} \mathrm{SP}$ in $\mathrm{R} 5, \mathrm{R} 6, \mathrm{R} 7$ & $\begin{array}{c}1-2 \mathrm{mg} / \mathrm{L} \mathrm{R} 5 \text { and R6 } \\
0.25-2 \mathrm{mg} / \mathrm{L} \mathrm{R} 7\end{array}$ & 1.50 \\
\hline & & Slave PI & $\mathrm{k}_{\mathrm{L}} \mathrm{a}$ in $\mathrm{R} 5, \mathrm{R} 6, \mathrm{R} 7$ & $0-160 \mathrm{~d}^{-1}$ & Imposed by MPC \\
\hline & $\mathrm{S}_{\mathrm{NO} 3}$ in $\mathrm{R} 4$ & PI & $\mathrm{Q}_{\mathrm{RINT}}$ & $0-92230 \mathrm{~m}^{3} / \mathrm{d}$ & 1.92 \\
\hline & $\mathrm{S}_{\mathrm{PO} 4}$ in $\mathrm{R} 2$ & PID & COD addition & $0-5 \mathrm{~m}^{3} \cdot \mathrm{d}^{-1}$ & 27.00 \\
\hline $\begin{array}{c}\text { Common } \\
\text { Control } \\
\text { loops }\end{array}$ & TSS in R7 & PI & Qw & $300-450 \mathrm{~m}^{3} / \mathrm{d}$ & 3850.00 \\
\hline
\end{tabular}


Table 8. Estimated total capital costs for each type of equipment used for the control strategies for an operation period (OP) of 5 years.

\begin{tabular}{|c|c|c|c|c|c|c|}
\hline Equipment Type & $\begin{array}{c}\mathbf{C C} \\
{[€ / \text { unit }]}\end{array}$ & $\begin{array}{c}\text { IC } \\
\text { [€/unit] }\end{array}$ & $\begin{array}{c}\text { OMC } \\
{[€ / \text { year] }}\end{array}$ & $\begin{array}{c}\mathbf{n} \\
\text { [years] }\end{array}$ & $\begin{array}{c}\mathbf{O E} \\
{[€ / \mathbf{O P}]}\end{array}$ & $\begin{array}{l}5 y T C C \\
{[€ / O P]}\end{array}$ \\
\hline PHOSPHAX & 11000 & 2200 & 2200 & 5 & 2420 & 26620 \\
\hline FILTRAX & 5300 & 1060 & 1060 & 5 & 1166 & 12826 \\
\hline LDO & 1300 & 260 & 260 & 5 & 286 & 3146 \\
\hline NO3D & 5100 & 1020 & 1020 & 5 & 1122 & 12342 \\
\hline NH4D & 5200 & 1040 & 1040 & 5 & 1144 & 12584 \\
\hline Controller & 1500 & 300 & 300 & 5 & 330 & 3630 \\
\hline $\begin{array}{l}\text { Data acquisition system } \\
\text { (DAS) }\end{array}$ & 4000 & 800 & 800 & 5 & 880 & 9680 \\
\hline
\end{tabular}


Table 9. Estimated total capital costs for each control strategy.

\begin{tabular}{|l|c|c|c|c|c|c|c|c|c|}
\hline & $\begin{array}{c}\text { PHOSPHAX } \\
\text { [Units] }\end{array}$ & $\begin{array}{c}\text { FILTRAX } \\
\text { [Units] }\end{array}$ & $\begin{array}{c}\text { LDO } \\
\text { [Units] }\end{array}$ & $\begin{array}{c}\text { NO3D } \\
\text { [Units] }\end{array}$ & $\begin{array}{c}\text { NH4D } \\
\text { [Units] }\end{array}$ & $\begin{array}{c}\text { Controller } \\
\text { [Units] }\end{array}$ & $\begin{array}{c}\text { DAS } \\
\text { [Units] }\end{array}$ & $\begin{array}{c}\text { TCC } \\
\text { [€/OP] }\end{array}$ & $\begin{array}{c}\text { dTCC } \\
\text { [€/day] }\end{array}$ \\
\hline CS1 & 1 & 1 & 3 & 1 & 0 & 5 & 1 & 89056 & 49 \\
\hline CS2 & 1 & 1 & 3 & 1 & 0 & 5 & 1 & 89056 & 49 \\
\hline CS3 & 1 & 1 & 3 & 2 & 0 & 6 & 1 & 105028 & 58 \\
\hline CS4 & 1 & 1 & 3 & 1 & 1 & 6 & 1 & 105270 & 58 \\
\hline
\end{tabular}


Table 10. Operational costs for the control strategies (S1)-(S4), open loop simulations (OL) and the optimized open loop simulation (OL+) for all influent files.

\begin{tabular}{|c|c|c|c|c|c|c|c|c|c|c|c|}
\hline inf & $\begin{array}{l}\text { Control } \\
\text { strategy }\end{array}$ & $\begin{array}{l}\text { AE } \\
\text { f/d }\end{array}$ & $\begin{array}{l}\text { PE } \\
€ / d\end{array}$ & $\begin{array}{l}E C \\
€ / d \\
\end{array}$ & $\begin{array}{l}\text { SP } \\
€ / d\end{array}$ & $\begin{array}{l}\text { SNH } \\
€ / d\end{array}$ & $\begin{array}{l}\text { Ptot } \\
\text { €/d }\end{array}$ & $\begin{array}{l}\text { Ntot } \\
\text { €/d }\end{array}$ & $\begin{array}{l}E \mathbf{E F} \\
€ / d\end{array}$ & $\begin{array}{l}\text { OC } \\
€ / d\end{array}$ & $\begin{array}{c}\mathrm{OC}+\mathrm{dTCC} \\
€ / \mathrm{d}\end{array}$ \\
\hline \multirow{6}{*}{ 类 } & OL & 360 & 39 & 0 & 490 & 169 & 683 & 638 & 1489 & 2378 & 2378 \\
\hline & OL+ & 382 & 51 & 181 & 502 & 181 & 432 & 483 & 1096 & 2212 & 2212 \\
\hline & CS1 & 349 & 49 & 171 & 522 & 143 & 298 & 512 & 953 & 2044 & 2093 \\
\hline & CS2 & 329 & 43 & 0 & 507 & 165 & 464 & 586 & 1215 & 2094 & 2143 \\
\hline & CS3 & 348 & 48 & 169 & 520 & 141 & 310 & 520 & 971 & 2057 & 2115 \\
\hline & CS4 & 350 & 47 & 181 & 522 & 77 & 303 & 512 & 891 & 1992 & 2050 \\
\hline \multirow{6}{*}{ Z } & OL & 360 & 39 & 0 & 460 & 385 & 1019 & 868 & 2272 & 3131 & 3131 \\
\hline & OL+ & 382 & 51 & 181 & 484 & 376 & 722 & 666 & 1764 & 2861 & 2861 \\
\hline & CS1 & 357 & 52 & 400 & 510 & 378 & 506 & 645 & 1529 & 2848 & 2897 \\
\hline & CS2 & 318 & 44 & 0 & 458 & 718 & 835 & 935 & 2488 & 3309 & 3358 \\
\hline & CS3 & 381 & 51 & 409 & 508 & 199 & 523 & 650 & 1371 & 2720 & 2778 \\
\hline & CS4 & 374 & 50 & 419 & 510 & 162 & 518 & 644 & 1324 & 2677 & 2735 \\
\hline \multirow{6}{*}{ 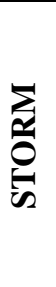 } & OL & 360 & 39 & 0 & 499 & 448 & 846 & 887 & 2180 & 3078 & 3078 \\
\hline & OLt & 382 & 51 & 181 & 509 & 425 & 592 & 676 & 1693 & 2816 & 2816 \\
\hline & CS1 & 361 & 49 & 232 & 527 & 315 & 466 & 705 & 1486 & 2655 & 2704 \\
\hline & CS2 & 336 & 42 & 0 & 524 & 358 & 885 & 873 & 2116 & 3018 & 3067 \\
\hline & CS3 & 362 & 48 & 232 & 526 & 292 & 474 & 710 & 1475 & 2644 & 2702 \\
\hline & CS4 & 373 & 46 & 255 & 528 & 131 & 484 & 704 & 1318 & 2520 & 2578 \\
\hline
\end{tabular}


Table 11. Mean effluent concentration and time above limits (TAL).

\begin{tabular}{|c|c|c|c|c|c|c|c|c|c|c|c|c|c|}
\hline \multirow[b]{2}{*}{ Inf } & \multirow[b]{2}{*}{$\begin{array}{l}\text { Contr } \\
\cdot \\
\text { Strat }\end{array}$} & \multicolumn{2}{|c|}{ SNH } & \multicolumn{2}{|c|}{ Ptot } & \multicolumn{2}{|c|}{ Ntot } & \multicolumn{2}{|c|}{ COD } & \multicolumn{2}{|c|}{ BOD } & \multicolumn{2}{|c|}{ TSS } \\
\hline & & $\begin{array}{c}\text { Conc } \\
\dot{m g} / \mathrm{L}\end{array}$ & $\underset{\%}{\text { TAL }}$ & $\begin{array}{c}\text { Conc } \\
\dot{m} / \mathrm{L}\end{array}$ & $\underset{\%}{\text { TAL }}$ & $\begin{array}{c}\text { Conc } \\
\dot{\mathrm{m}} \mathbf{L} .\end{array}$ & $\begin{array}{c}\text { TAL } \\
\%\end{array}$ & $\begin{array}{c}\text { Conc } \\
\dot{m} / \mathbf{L}\end{array}$ & $\begin{array}{c}\text { TA } \\
\text { L } \\
\% \\
\end{array}$ & $\begin{array}{c}\text { Conc } \\
\dot{m} / \mathrm{L}\end{array}$ & $\begin{array}{c}\text { TA } \\
\text { L } \\
\% \\
\end{array}$ & $\begin{array}{c}\text { Conc } \\
\dot{m} / \mathbf{L}\end{array}$ & $\begin{array}{c}\text { TA } \\
\text { L } \\
\% \\
\end{array}$ \\
\hline \multirow{6}{*}{$\hat{a}$} & OL & 1.60 & $\begin{array}{c}41.6 \\
0\end{array}$ & 1.62 & $\begin{array}{c}85.7 \\
4\end{array}$ & 11.01 & $\begin{array}{c}98.9 \\
6\end{array}$ & 44.03 & 0.00 & 1.84 & 0.00 & 13.62 & 0.00 \\
\hline & OL+ & 1.72 & $\begin{array}{c}43.9 \\
8\end{array}$ & 1.25 & $\begin{array}{c}77.4 \\
1\end{array}$ & 9.58 & $\begin{array}{c}26.4 \\
5\end{array}$ & 44.41 & 0.00 & 1.92 & 0.00 & 13.98 & 0.00 \\
\hline & CS1 & 1.54 & $\begin{array}{c}28.8 \\
3\end{array}$ & 1.07 & $\begin{array}{c}60.9 \\
2\end{array}$ & 9.72 & $\begin{array}{c}51.7 \\
1\end{array}$ & 44.05 & 0.00 & 1.90 & 0.00 & 13.64 & 0.00 \\
\hline & CS2 & 1.63 & $\begin{array}{c}28.0 \\
8\end{array}$ & 1.31 & $\begin{array}{c}89.6 \\
0\end{array}$ & 10.52 & $\begin{array}{c}64.6 \\
4\end{array}$ & 43.97 & 0.00 & 1.85 & 0.00 & 13.61 & 0.00 \\
\hline & CS3 & 1.56 & $\begin{array}{c}37.4 \\
4\end{array}$ & 1.09 & $\begin{array}{c}65.8 \\
2\end{array}$ & 9.85 & $\begin{array}{c}50.8 \\
2\end{array}$ & 44.05 & 0.00 & 1.89 & 0.00 & 13.64 & 0.00 \\
\hline & CS4 & 1.10 & 0.59 & 1.09 & $\begin{array}{c}65.2 \\
3\end{array}$ & 9.62 & $\begin{array}{c}47.1 \\
0\end{array}$ & 44.05 & 0.00 & 1.90 & 0.00 & 13.65 & 0.00 \\
\hline \multirow{6}{*}{$\underset{z}{Z}$} & OI & 2.06 & $\begin{array}{c}51.4 \\
1\end{array}$ & 1.77 & $\begin{array}{c}91.8 \\
3\end{array}$ & 11.18 & $\begin{array}{c}87.5 \\
2\end{array}$ & 40.51 & 0.00 & 2.12 & 0.00 & 15.67 & 0.00 \\
\hline & OL+ & 2.09 & $\begin{array}{c}52.0 \\
1\end{array}$ & 1.39 & $\begin{array}{c}85.8 \\
8\end{array}$ & 9.81 & $\begin{array}{c}43.9 \\
8\end{array}$ & 41.01 & 0.00 & 2.22 & 0.00 & 16.14 & 0.00 \\
\hline & CS1 & 2.17 & $\begin{array}{c}52.6 \\
0\end{array}$ & 1.15 & $\begin{array}{c}68.0 \\
5\end{array}$ & 9.53 & $\begin{array}{c}37.8 \\
9\end{array}$ & 40.69 & 0.00 & 2.24 & 0.00 & 15.76 & 0.00 \\
\hline & CS2 & 3.03 & $\begin{array}{c}53.4 \\
9\end{array}$ & 1.47 & $\begin{array}{c}90.7 \\
9\end{array}$ & 11.35 & $\begin{array}{c}80.8 \\
3\end{array}$ & 42.01 & 0.00 & 2.35 & 0.00 & 17.18 & 6.24 \\
\hline & CS3 & 1.61 & $\begin{array}{c}36.1 \\
1\end{array}$ & 1.17 & $\begin{array}{c}72.5 \\
1\end{array}$ & 9.58 & $\begin{array}{c}41.6 \\
0\end{array}$ & 40.65 & 0.00 & 2.22 & 0.00 & 15.75 & 0.00 \\
\hline & CS4 & 1.35 & $\begin{array}{c}12.3 \\
3 \\
\end{array}$ & 1.17 & $\begin{array}{c}73.8 \\
5 \\
\end{array}$ & 9.42 & $\begin{array}{c}37.7 \\
4 \\
\end{array}$ & 40.67 & 0.00 & 2.23 & 0.00 & 15.76 & 0.00 \\
\hline \multirow{6}{*}{ 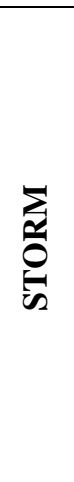 } & OL & 2.59 & $\begin{array}{c}53.1 \\
9\end{array}$ & 1.67 & $\begin{array}{c}85.1 \\
4\end{array}$ & 11.84 & $\begin{array}{c}93.7 \\
6\end{array}$ & 42.06 & 0.00 & 2.02 & 0.00 & 14.99 & 3.86 \\
\hline & OL+ & 2.59 & $\begin{array}{c}54.0 \\
9\end{array}$ & 1.32 & $\begin{array}{c}78.9 \\
0\end{array}$ & 10.41 & $\begin{array}{c}54.6 \\
8\end{array}$ & 42.36 & 0.00 & 2.09 & 0.00 & 15.25 & 3.57 \\
\hline & CS1 & 2.17 & $\begin{array}{c}46.2 \\
1\end{array}$ & 1.15 & $\begin{array}{c}64.3 \\
4\end{array}$ & 10.37 & $\begin{array}{c}54.6 \\
8\end{array}$ & 42.08 & 0.00 & 2.08 & 0.00 & 14.97 & 3.71 \\
\hline & $\mathrm{CS} 2$ & 2.37 & $\begin{array}{c}46.2 \\
1\end{array}$ & 1.56 & $\begin{array}{c}89.1 \\
5\end{array}$ & 11.60 & $\begin{array}{c}81.2 \\
8\end{array}$ & 44.10 & 2.23 & 2.30 & 2.38 & 17.03 & 6.39 \\
\hline & CS3 & 2.05 & $\begin{array}{c}43.9 \\
8\end{array}$ & 1.16 & $\begin{array}{c}68.3 \\
5\end{array}$ & 10.44 & $\begin{array}{c}56.6 \\
1\end{array}$ & 42.07 & 0.00 & 2.08 & 0.00 & 14.97 & 3.71 \\
\hline & CS4 & 1.32 & $\begin{array}{c}12.7 \\
8\end{array}$ & 1.17 & $\begin{array}{c}73.2 \\
5\end{array}$ & 10.24 & $\begin{array}{c}52.7 \\
5\end{array}$ & 42.10 & 0.00 & 2.09 & 0.00 & 15.00 & 3.86 \\
\hline
\end{tabular}


Table 12. WWTP performance for pollutant removal.

\begin{tabular}{|c|c|c|c|c|c|c|c|}
\hline \multirow[t]{2}{*}{ Inf. } & \multirow{2}{*}{$\begin{array}{c}\text { Contr. } \\
\text { Strat }\end{array}$} & \multicolumn{6}{|c|}{ Pollutant Removal (\%) } \\
\hline & & SNH & Ptot & Ntot & COD & BOD & TSS \\
\hline \multirow{6}{*}{$\grave{a}$} & OL & 95.72 & 86.31 & 73.85 & 88.40 & 99.06 & 93.28 \\
\hline & OL+ & 95.43 & 89.44 & 77.24 & 88.30 & 99.02 & 93.10 \\
\hline & CS1 & 95.90 & 90.95 & 76.93 & 88.40 & 99.03 & 93.26 \\
\hline & $\mathrm{CS} 2$ & 95.65 & 88.98 & 75.03 & 88.42 & 99.06 & 93.28 \\
\hline & CS3 & 95.85 & 90.80 & 76.62 & 88.40 & 99.03 & 93.27 \\
\hline & CS4 & 97.06 & 90.84 & 77.16 & 88.40 & 99.03 & 93.26 \\
\hline \multirow{6}{*}{$\underset{\Omega}{Z}$} & OL & 93.89 & 83.16 & 70.30 & 87.43 & 98.73 & 90.59 \\
\hline & OL+ & 93.80 & 86.71 & 73.95 & 87.28 & 98.67 & 90.30 \\
\hline & CS1 & 93.57 & 89.04 & 74.69 & 87.38 & 98.66 & 90.54 \\
\hline & CS2 & 91.01 & 85.96 & 69.86 & 86.97 & 98.59 & 89.68 \\
\hline & CS3 & 95.23 & 88.84 & 74.54 & 87.39 & 98.67 & 90.54 \\
\hline & CS4 & 96.01 & 88.82 & 74.98 & 87.38 & 98.66 & 90.54 \\
\hline \multirow{6}{*}{$\sum_{\substack{0 \\
0}}$} & OL & 93.11 & 85.84 & 71.86 & 88.52 & 98.92 & 92.16 \\
\hline & OL+ & 93.13 & 88.81 & 75.28 & 88.43 & 98.89 & 92.03 \\
\hline & CS1 & 94.25 & 90.27 & 75.37 & 88.51 & 98.89 & 92.17 \\
\hline & CS2 & 93.70 & 86.78 & 72.45 & 87.96 & 98.77 & 91.09 \\
\hline & CS3 & 94.55 & 90.17 & 75.21 & 88.51 & 98.89 & 92.17 \\
\hline & CS4 & 96.50 & 90.03 & 75.67 & 88.51 & 98.89 & 92.15 \\
\hline
\end{tabular}




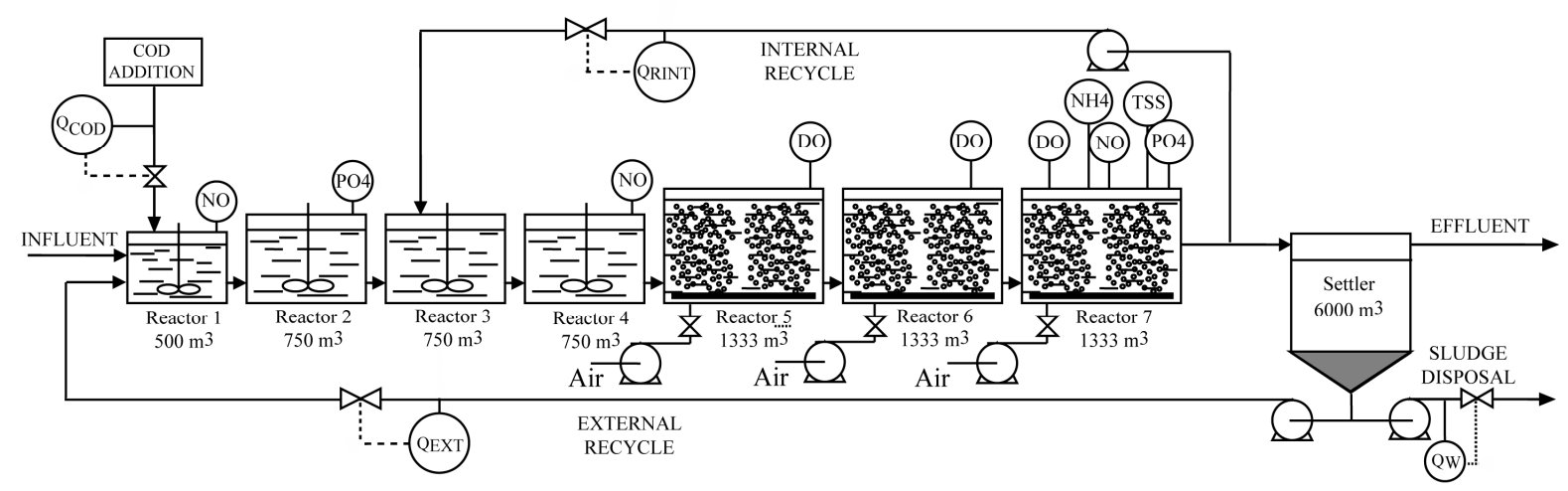

Figure 1 Scheme of the A2/O simulated plant for simultaneous C/N/P removal. 

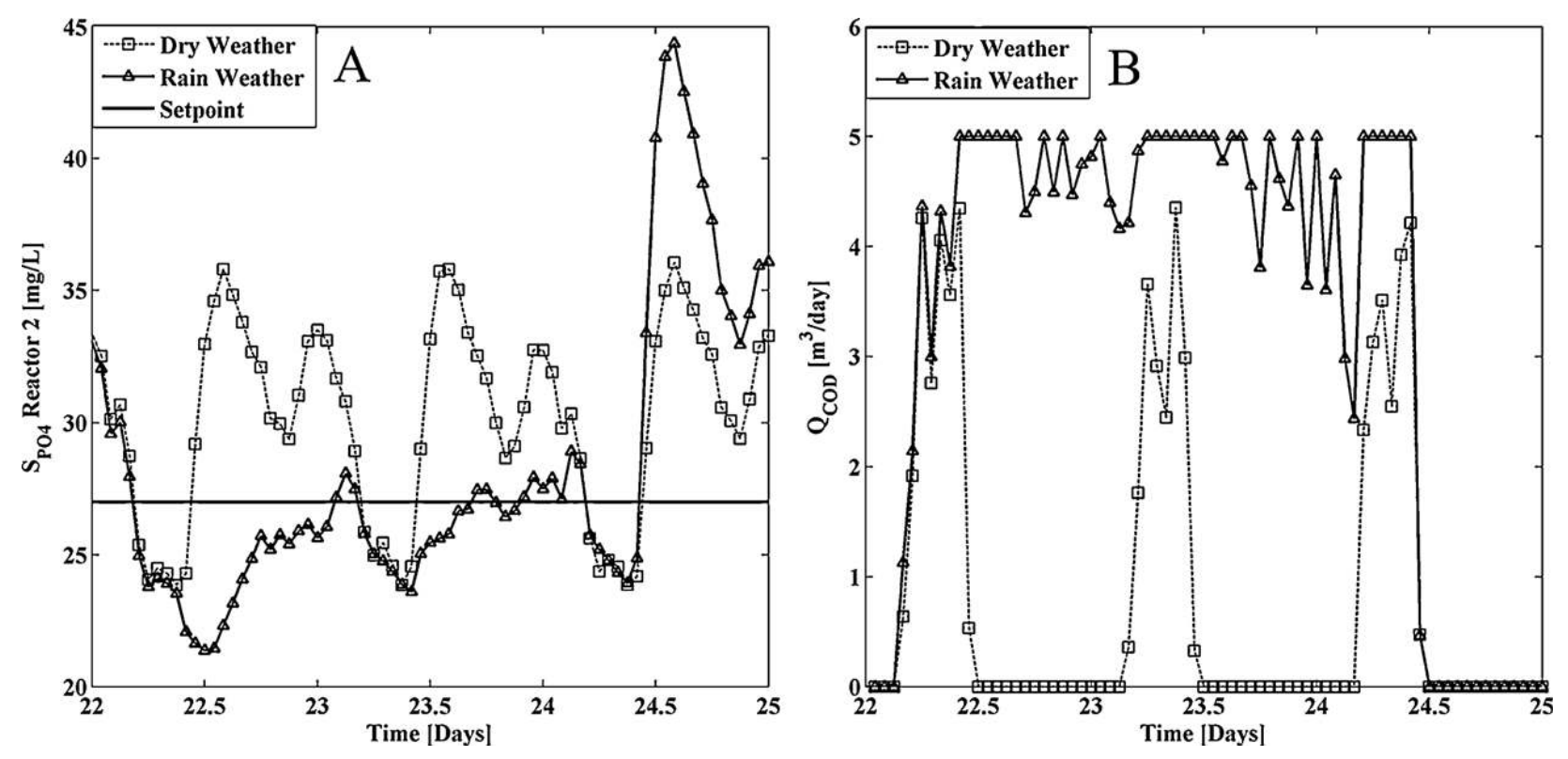

Figure 2 CS1 variation of phosphorus in reactor 2 (A) and QCOD (B) for the dry and rain influent file. 



Figure 3 Dynamics of the CS2 under dry and rain weather conditions: A) SPO4 reactor 2; B)

QREXT; C) Effluent TSS; D) Effluent Ptot 

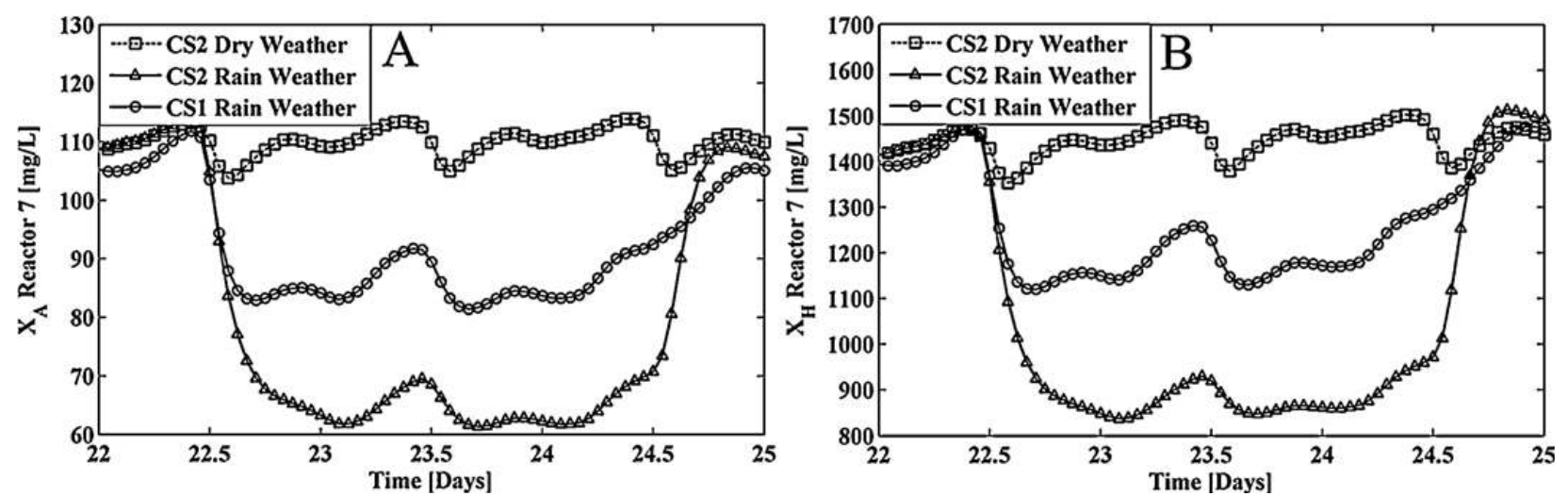

Figure 4 Variation of the autotrophic (A) and heterotrophic (B) biomass for CS1 and CS2. 

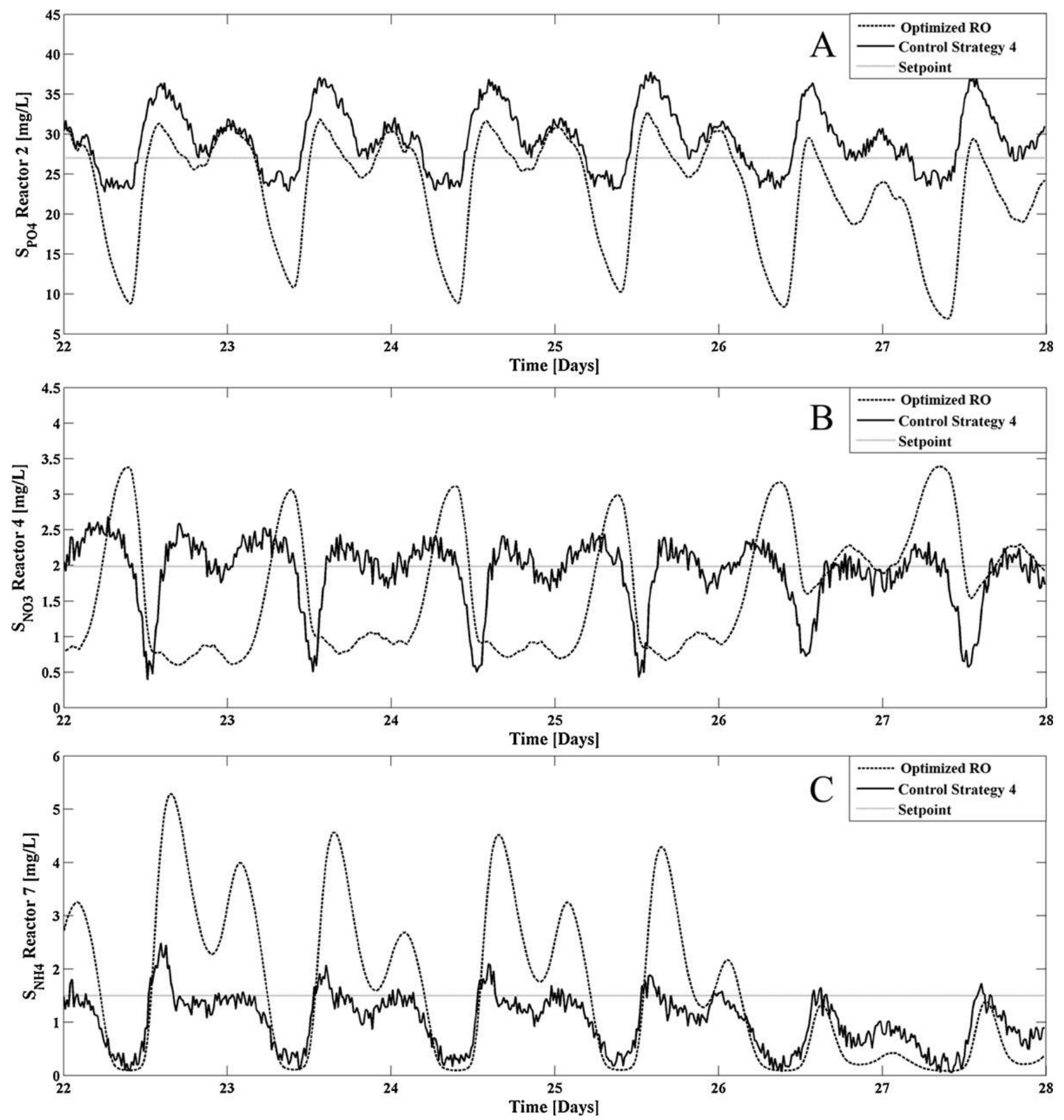

Figure 5 Control strategy CS4 results for the Dry influent file: (A) Phosphate R2; (B) Nitrate nitrogen R4; (C) Ammonia R7 



Figure 6 Control strategy CS4 dynamics of the manipulated variables: (A) External carbon addition flow; (B) QRINT; (C) kLa R5; (D) kLa R6; (E) kLa R7 


\section{Supplementary data.}


Fig 1. Agreement between the simulated A2/O WWTP and the LTI state space models used for the MPC. 